\title{
Tectonic evolution of the southern margin of the Amazonian craton in the late Mesoproterozoic based on field relationships and zircon $\mathrm{U}-\mathrm{Pb}$ geochronology
}

\author{
GILMAR J. RIZZOTTO ${ }^{1}$, LÉO A. HARTMANN ${ }^{2}$, JOÃO O.S. SANTOS ${ }^{3}$ and NEAL J. MCNAUGHTON ${ }^{4}$ \\ ${ }^{1}$ Serviço Geológico do Brasil (CPRM), Rua 148, n 485, Setor Marista, 74170-110 Goiânia, GO, Brasil \\ ${ }^{2}$ Instituto de Geociências, Universidade Federal do Rio Grande do Sul, \\ Avenida Bento Gonçalves, 9500, 91501-970 Porto Alegre, RS, Brasil \\ ${ }^{3}$ Redstone Resources, Suite 3, 110 East Parade, 6004, East Perth, WA, Australia \\ ${ }^{4}$ Curtin University of Technology, GPO Box U1987, 6845, Bentley, WA, Australia
}

Manuscript received on May 31, 2012; accepted for publication on November 6, 2012

\begin{abstract}
New U-Pb zircon geochronological data integrated with field relationships and an airborne geophysical survey suggest that the Nova Brasilândia and Aguapeí belts are part of the same monocyclic, metaigneous and metasedimentary belt formed in the late Mesoproterozoic (1150 Ma-1110 Ma). This geological history is very similar to the within-plate origin of the Sunsás belt, in eastern Bolivia. Thus, we propose that the Nova Brasilândia, Aguapeí and Sunsás belts represent a unique geotectonic unit (here termed the Western Amazon belt) that became amalgamated at the end of the Mesoproterozoic and originated through the reactivation of a paleo-suture (Guapore suture zone) in an intracontinental rift environment. Therefore, its geological history involves a short, complete Wilson cycle of ca. 40 Ma. Globally, this tectonic evolution may be related with the final breakup of the supercontinent Columbia. Mafic rocks and trondhjemites in the northernmost portion of the belt yielded U-Pb zircon ages ca. $1110 \mathrm{Ma}$, which dates the high-grade metamorphism and the closure of the rift. This indicates that the breakup of supercontinent Columbia was followed in short sequence by the assembly of supercontinent Rodinia at ca. 1.1-1.0 Ga and that the Western Amazon belt was formed during the accretion of the ArequipaAntofalla basement to the Amazonian craton.
\end{abstract}

Key words: Amazonian craton, intracontinental rift, Mesoproterozoic, Western Amazon belt, U-Pb geochronology.

\section{INTRODUCTION}

The Amazonian craton constitutes a central core of the South American continent and it was formed by the amalgamation of Proterozoic accretionary belts that are successively younger toward the southwestern border of the craton (Cordani et al. 2000, Santos et al. 2000, 2008). This continental

Correspondence to: Gilmar José Rizzotto

E-mail: grgilmarjose@gmail.com landmass has participated in major paleogeographic reconstructions, such as the formation of the Columbia and Rodinia supercontinents (e.g., Rogers and Santosh 2003, Li et al. 2008). The Rodinia supercontinent was formed in the late Mesoproterozoic to early Neoproterozoic by the agglutination of the existing cratonic fragments, such as Amazonia and Laurentia. In Amazonia, the records of this agglutination are present in the 
southwesternmost part of the Amazonian craton. This region is composed of rocks belonging to the Sunsás Orogen, according to Santos et al. (2008), or the Rondonian-San Ignacio Province (Tassinari et al. 1996). The first authors proposed that the Sunsás Orogen is characterized by an autochthonous evolution that lasted for 360 m.y. (from 1465 to $1110 \mathrm{Ma}$ ) and was formed by four orogenies: Santa Helena (1460-1420 Ma), Candeias (1370-1320 Ma), San Andrés (1275 Ma) and Nova Brasilândia (1180-1110 Ma). They also postulated the nonexistence of the Paraguá craton, a cratonic fragment that consists of metamorphic basement rocks in the eastern Bolivia Precambrian shield, which was first defined by Litherland et al. (1986), and argued that Paraguá "craton" and Amazonia were already close together, as parts of the same continental masses in the middle to late Mesoproterozoic. In the same way, Sadowski and Bettencourt (1996) argued that there is no clear evidence that the Paraguá craton is a unit that is independent from the Amazonian craton, and they consider it to be part of the Amazonian craton that is defined as the Paraguá Block.

Additionally, Bettencourt et al. (2010), in a recent review of the evolutionary history of the Rondonian-San Ignacio Province, characterized the Province as a composite orogen, consisting of an older, complex accretionary orogen (1556-1430 Ma) that was followed by the collision of the Paraguá Block with the southern part of the cratonized Amazonian craton at 1340-1320 Ma.

The proposal for the tectonic framework of the Amazon made by Tohver et al. (2004, 2005a, b, 2006) draws a comparison between the Grenville history recorded in the SW Amazonian craton with that observed in southernmost Laurentia. They propose that during the late Mesoproterozoic, the SW Amazonian craton was marked by two separate tectonic events, the first related to collision with southern Laurentia (ca. 1.2-1.15 Ga) and the second caused by suturing of the Paraguá craton (ca. $1.09 \mathrm{Ga}$ ). These researchers also suggest the existence of a suture belt (Nova Brasilândia belt) indicating that the initial docking of the Amazonian craton with southern Laurentia (Llano uplift) at 1.2 Ga was followed by strike-slip motion, allowing for later suturing of the Paraguá craton in the final stages of the amalgamation of Rodinia. They also suggest that the Nova Brasilândia sedimentation occurred during a transtensional phase at $<1.2 \mathrm{Ga}$.

In contrast, alternative positions of the Amazonian craton in Mesoproterozoic are envisaged to accommodate smaller crustal fragments, such as the Arequipa-Antofalla (i.e., Keppie and Ortega-Gutierrez 1999, Loewy et al. 2003, 2004, Casquet et al. 2006). In this way, Boger et al. (2005) present three possible scenarios for the accretion of the Paraguá Block and the Arequipa-Antofalla basement to the western margin of the Amazonian craton. Nevertheless, latest authors favor the tectonic model by which the Paraguá Block was accreted to the margin of a coherent Amazonian craton during the Sunsás Orogeny.

The tectonic framework of the Amazon basement (Rondônia-Juruena Province) is of a multi-orogenic nature, whereas the adjacent Nova Brasilândia Group in the Nova Brasilândia belt most likely originated in an intracontinental rift setting. Rifting was followed by the opening of a proto-ocean at $<1215 \mathrm{Ma}$ as part of a single Wilson cycle (Rizzotto 1999).

With a similar geochronological and tectonic evolution, the Sunsás and Aguapeí belts occur along the southeastern rim of the Paraguá Block. These belts are most likely related to the timing of an intraplate extension episode, a stage equivalent to the Nova Brasilândia belt passive margin. The deposition age of the Aguapeí Group occurred between $1167 \pm 27 \mathrm{Ma}$ and $1149 \pm 7 \mathrm{Ma}$ (Santos et al. 2005). However, Tohver et al. (2004, 2005a) and Teixeira et al. (2010) suggest the absence of physical and structural continuity between the northernmost extent of the Aguapeí belt and the 
E-W trending Nova Brasilândia belt. Teixeira et al. (2010) suggest that the Aguapeí belt is a late tectonic component of the Sunsás province as a result of the Sunsás collision.

The estratigraphic correlation between the Aguapeí and Sunsás Group is in agreement with the idea that late Mesoproterozoic extensional dynamics produced a system of continental, aborted rifts over the cratonized SW margin of the Amazonian craton, evolving to a wide intracratonic basin (e.g., Leite and Saes 2003).

Therefore, the inconsistencies regarding the collided Paraguá Block-Amazonian craton and its geodynamic behavior during the Mesoproterozoic are under evaluation. However, Rizzotto and Hartmann (2012) suggested a new scenario for the operation of Mesoproterozoic plate tectonics, with the definition of the Guaporé suture zone, a mega-structure that marks the suturing of the protoAmazonian craton and the Paraguá Block in the late Calymmian to middle Ectasian, ca. 1470-1320 Ma. The Guaporé suture is a zone of crustal weakness reactivated during sedimentation and the protooceanic opening of the Nova Brasilândia basin.

In this paper, we present new zircon $\mathrm{U}-\mathrm{Pb}$ geochronological results from the two Mesoproterozoic Nova Brasilândia and Aguapeí orogenies of the southwestern Amazonian craton, coupled with field relationships, in a contribution to resolved some of these issues. These results place new delimitations on the geologic evolution of the southwestern margin of the Amazonian craton, and this sheds light on paleogeographic correlations between Amazonia and Laurentia.

\section{GeOlogical OvervieW}

The studied area is located between the Sunsás and Rondônia-Juruena Provinces (Santos et al. 2008), southwestern Amazonian craton (Fig. 1). The basement rocks of the Rondônia-Juruena Province are included in six major Paleo-Mesoproterozoic terranes and events: the Juruena magmatic arc, the Jamari magmatic arc, the Alto Jauru Terrane, the Quatro Cachoeiras orogeny, the Cachoerinha orogen and the Anorogenic magmatism (Fig. 1).

The Paleoproterozoic basement rocks of the Sunsás Province (Paraguá Block) (Fig. 1) comprise three main units: the Lomas Manechi Complex display granulitic metamorphism generated during the Mesoproterozoic, at ca. 1330-1350 Ma (Santos et al. 2008). The Chiquitania Complex and San Ignacio Group subsequently deformed and metamorphosed during the San Ignacio Orogeny by means of three successive events of deformation accompanied by voluminous syn-tectonic granite magmatism (Litherland et al. 1986).

This Paleoproterozoic basement was amalgamated along WNW-trending Mesoproterozoic belts, described here from oldest to youngest. The Alto Guaporé belt (Rizzotto and Dehler 2007) is a accretionary orogen formed by oceanic plate subduction between 1.47-1.43 Ga (Rizzotto and Hartmann 2012). This constitutes the Guaporé suture zone between the proto-Amazonian craton and the Paraguá Block. The rocks of the Alto Guaporé belt are exposed from the northwestern sector of Rondônia state to the southeastern and to the southwestern portion of Mato Grosso state. They are largely covered by the Cenozoic sedimentary rocks of the Parecis and Guaporé Basins, in an area of 200 x $60 \mathrm{~km}$, with WNW-ESE trend marked by strong magnetic anomalies. This belt consists predominantly of, plutonic, sedimentary and mafic-ultramafic volcanic rocks of the Trincheira Complex and calcalkaline granitic rocks. The Colorado Complex is a meta-sedimentary sequence occurring in the Guaporé suture and is composed of paragneiss, pelitic schist, calc-silicate gneiss, para-amphibolite and banded iron formation. The protolith of the paragneiss and pelitic schist is interpreted as a turbiditic sequence deposited in a passive margin (Rizzotto and Quadros 2007).

The Nova Brasilândia and Aguapeí belts (ca. 1150-950 Ma) are exposed along the BoliviaBrazil border (Fig. 2). The Nova Brasilândia belt 


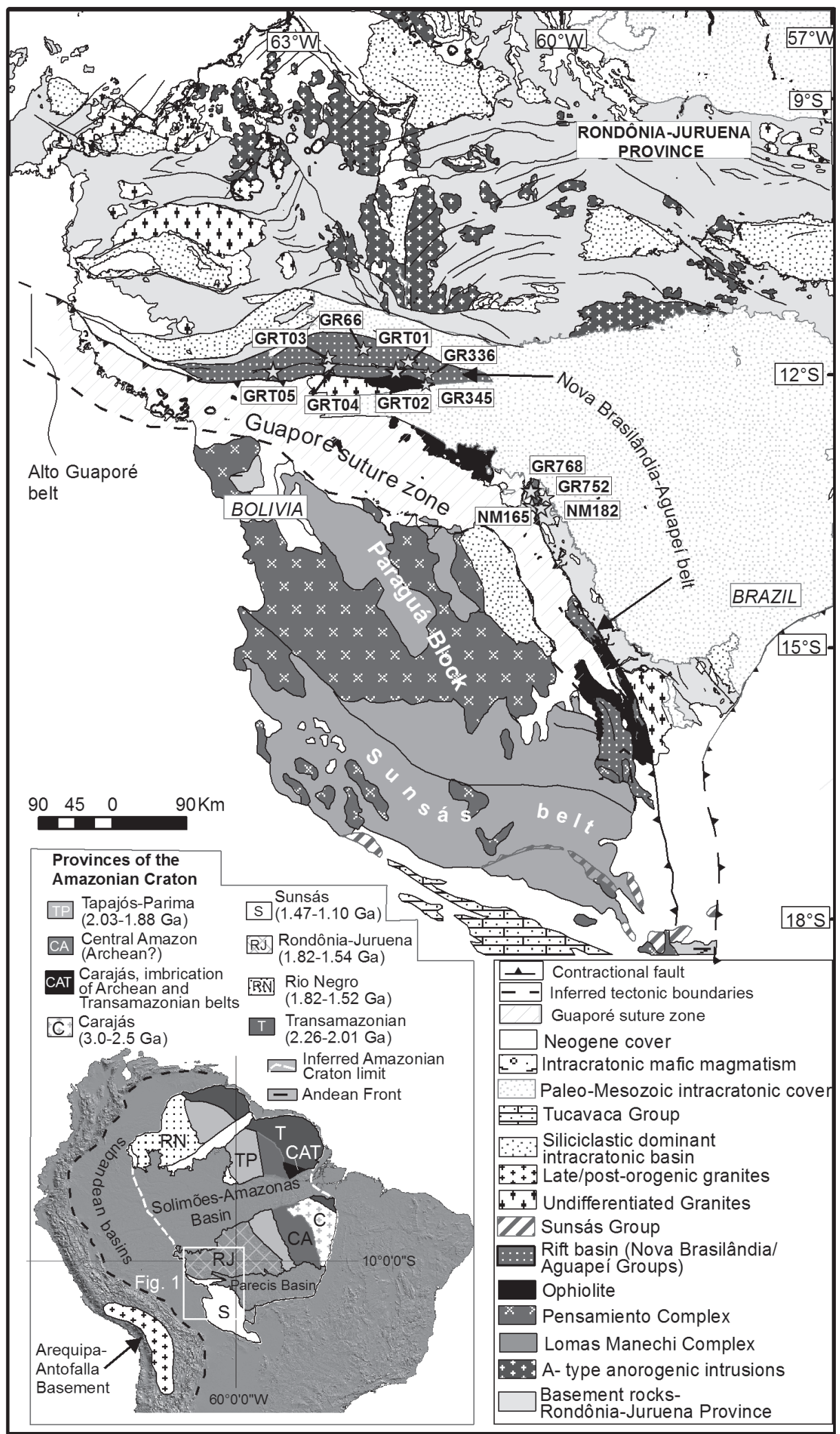

Figure 1 - Simplified map of the southwestern Amazonian craton showing the approximate boundaries of the main Provinces, belts, tectonic elements, lithologic units, and location of dated samples. 


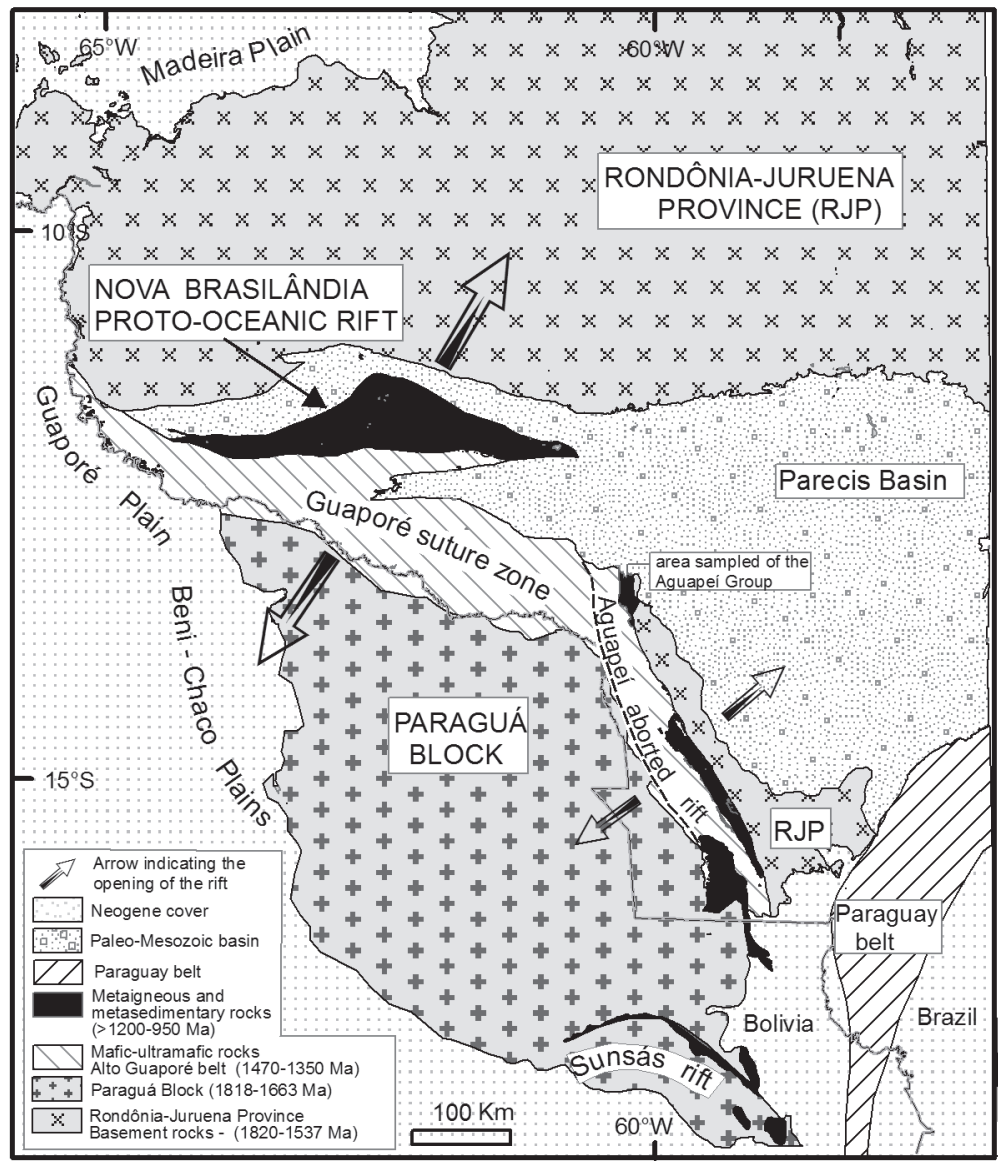

Figure 2 - Geotectonic map of the southwestern Amazonian craton highlighting the Nova Brasilândia, Aguapeí and Sunsás rifts.

originated from the opening and closing of an ocean, whereas the Aguapeí belt is an aborted rift, both generated by reactivation along the Guaporé suture zone at ca. 1110-950 Ma.

The region being examined comprises the Nova Brasilândia and Aguapeí belts, with the integration of new field and geochronological data. The Sunsás belt is also described for comparison. The importance of the theme is centered on the register of the last orogenic phase in the southwestern border of the Amazonian craton and its correlation with the Grenville province in southern Laurentia.

\section{Grenvillian-age deformation in the basement of the Rondonia-Juruena Province}

The timing of the deformation and generation of orogenic rocks of Stenian age in the southwestern
Amazonian craton was first estimated by Rizzotto (1999) using U-Pb geochronology in the Nova Brasilândia belt. To the north of this belt, the granitoid basement rocks of the Rondônia-Juruena Province record a polycyclic evolution characterized by the complex juxtaposition of distinct units and widespread shear zone structures.

The granitoid basement rocks were sheared by a wide network of sinistral, amphibolite-grade, strike-slip shear zones defined as the Ji-Paraná shear zone (Scandolara et al. 1999) which extends over hundreds of kilometers and cross-cut all preexisting rock fabrics. According to Tohver et al. (2005a), metamorphism along the shear zone occurred at temperatures of $450-550^{\circ} \mathrm{C}$, and the timing of this deformation varies from ca. 1.18 to 1.15 Ga. Consistent with these findings, recent data 
from field work in central Rondônia by Quadros et al. (2012) defined the Ji-Paraná-Cujubim transpressional sinistral system as extending to the northwest of the Ji-Paraná shear zone. Within this zone, the Igarapé Quinze Formation consists of paragneisses and schists that trend $\mathrm{N} 40 \mathrm{~W}$. The dating of detrital zircon from the schist yielded $\mathrm{U}-\mathrm{Pb}$ ages in the range of $1940 \mathrm{Ma}$ and $1367 \mathrm{Ma}$. The younger age is interpreted as the maximum age of sedimentation of the sedimentary protoliths of the Igarapé Quinze Formation (Quadros et al. 2012). This formation is interpreted as turbiditic deposits and the tectonic structures allow its correlation with the Nova Brasilândia Group (Quadros et al. 2012).

According to these authors, lenses and pods of anatectic granite were generated by partial melting of metapelites. Zircons grains from a locallyderived anatetic melt yield a U-Pb age of $1138 \pm$ $8 \mathrm{Ma}$. This age represents the peak metamorphic conditions experencied by the sedimentary protolith along the Ji-Paraná-Cujubim belt.

\section{NoVA BRASILÂNDIA BELT}

The Nova Brasilândia Group in the Nova Brasilândia belt consisted originally of a supracrustal unit of deepsea turbidites with a siliceous-clastic-to-carbonatic composition. The unit was metamorphosed in upperamphibolite to granulite facies to produce quartzfeldspar gneisses, mica schists and minor calcsilicate gneisses. The metasedimentary package also includes metagabbro sills, amphibolites and scarce metabasalts. SHRIMP U-Pb analyses of detrital zircons grains from the Nova Brasilândia pelitic rocks yield ages that range from ca. $2090 \pm 17$ Ma to $1122 \pm 12 \mathrm{Ma}$. The main population of zircon has an age of $1215 \mathrm{Ma}$, interpreted by Rizzotto (1999) as the maximum deposition age for the sequence. Sample reprocessing shows a younger group of zircon grains with an age of $1122 \pm 12 \mathrm{Ma}$, interpreted as the age of the basin opening (see section 4).

The other unit consists of mafic sills that outcrop in a narrow and elongated WNW-ESSE belt of voluminous plutonic mafic rocks with a strong, positive magnetic signature (Fig. 3). This magmatism is related to the successful initial rifting that formed a narrow proto-ocean, currently with approximately $12 \times 110 \mathrm{~km}$, during the evolution of continental to oceanic rift phase. These mafic rocks are here considered to record an extensional anorogenic magmatism associated with fragmentation of a preRodinia supercontinent.

This mafic unit is bordered in the north by a transcurrent sinistral shear zone, which consists of mafic granulites (norite and gabbro as protoliths), rare acid granulites, banded amphibolites, porphyroblastic amphibolites, and interbedded trondhjemites, diabase dikes and lenses of calcsilicate gneisses. Rare and scattered basalts, metasedimentary rocks and banded iron formation indicate a high degree of exhumation of the terrain with the accompanying erosion of the top portion of the volcano-sedimentary rocks. The Rio Branco monzogranitic orthogneiss was emplaced under a transpressive regime in the banded amphibolite at ca. $1113 \mathrm{Ma}$, with $\mathrm{T}_{\mathrm{DM}}=1630 \mathrm{Ma}$ (Rizzotto 1999).

The transtensional stage was succeeded by a transpressional regime accompanied by crustal shortening, as evidenced by regional EW- and WNWESE-trending structures, dominated by oblique thrust faults (D1). The northeast vergence and medium-to high-grade metamorphism correspond to a progressive thrust to transcurrent shear zones with tectonic transport from SSW to NNE. The main extensional structures are oriented in the $\mathrm{N} 45^{\circ} \mathrm{E}$ direction, while the structures with a direction of $\mathrm{N} 45^{\circ} \mathrm{W}$ correspond to a frontal thrust. The synkinematic emplacement of the Rio Branco granite and anatectic leucogranite $(1110 \pm 8 \mathrm{Ma})$ was contemporaneous with this compressional stage. These are the first Grenvillianage orogenic rocks within the Nova Brasilândia belt described by Rizzotto (1999) within the southwestern margin of the Amazonian craton.

The geological history of the Nova Brasilândia belt is supplemented with the emplacement of the 


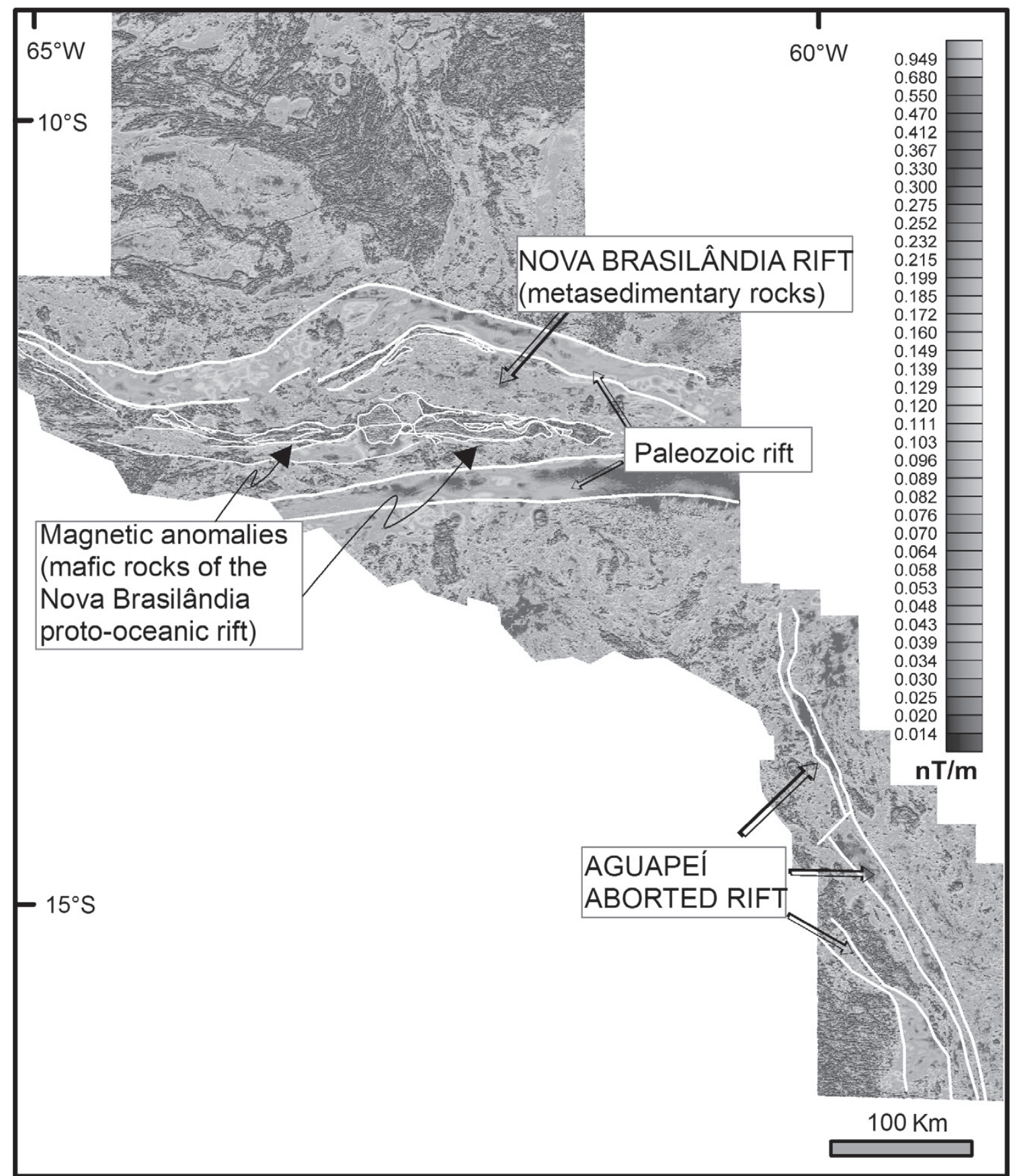

Figure 3 - Magnetometric data (analytical signal amplitude map) of southwestern margin of the Amazonian craton. The highlighted (white line) magnetic lineaments indicate the rift zones and areas with mafic rocks outcrops of the Nova Brasilândia proto-oceanic rift phase.

Rio Pardo granite, which comprises a kilometersized syn- to late transcurrent body with an age of the $1005 \pm 41 \mathrm{Ma}$, injected during the development of transcurrent shear zones.
Thus, the Nova Brasilândia Group originated in an intracontinental rift setting followed by the opening of a proto-ocean and was further subjected to crustal shortening, deformation and associated 
magmatism. This is suggested by detailed structural studies and metamorphic petrology coupled with chemical and petrogenetic constraints determined from the sedimentary and igneous rocks (Rizzotto 1999). This scenario is supported by recent paleomagnetic results reported by D'Agrella-Filho et al. (2012) where the 1420 Ma Indiavaí and Nova Guarita poles suggest that the Nova Brasilândia belt does not represent a suture zone, but rather an intracratonic structure.

In contrast, Tohver et al. (2004, 2005a) interpreted the Nova Brasilândia belt as the result of the crustal thickening through imbrication caused by the transpressive suturing of the Amazonian and Paraguá cratons at ca. $1.09 \mathrm{Ga}$. They used detailed structural data, supported by thermobarometric calculations and geochronological information. Metamorphic ages (U-Pb in titanite and monazite; ${ }^{40} \mathrm{Ar} /{ }^{39} \mathrm{Ar}$ in amphibole and biotite) range from 1.09-1.06 Ga to 0.97-0.91 Ga throughout the belt (e.g., Tohver et al. 2004, 2006). This age range reveals a long history of metamorphism, tectonic exhumation and cooling.

According to Rizzotto (2001), the distensional phase and final orogenic collapse (1005-970 Ma) of the Nova Brasilândia belt was accompanied by late to post-tectonic granites dated at $1.05 \mathrm{Ga}(\varepsilon \mathrm{Nd}(\mathrm{T})$ $=+0.5)$, with the generation of the foreland basins (Palmeiral Formation) in a cratonic stabilization phase accompanied by bimodal intraplate magmatism. This stage was accompanied by lateral movements of crustal blocks that generated large strike-slip zones (Rio Branco shear zone). This is in agreement with the ${ }^{40} \mathrm{Ar} /{ }^{39} \mathrm{Ar}$ and $\mathrm{K}-\mathrm{Ar}$ analyses on amphibole from amphibolite (Tohver et al. 2004) and muscovite from granitic mylonite (Tassinari 1993), respectively, along this strike-slip zone. These analyses yielded a minimum age of metamorphism and deformation $\left(\mathrm{D}_{2}\right)$ at $970-966$ Ma and $965 \pm 23$ Ma. Similar ages were obtained by Fernandes et al. (2006) in sericite of the metarenites and metaconglomerates of the Aguapeí Group.
AGUAPEÍ BELT

The Aguapeí belt consists of a narrow metasedimentary belt that borders the eastern margin of the Paraguá Block in the southwestern Mato Grosso state. It comprises a folded metasedimentary unit (Aguapeí Group) deposited in an NNW-SSE trending aulacogen (Saes 1999) or in a rift environment (Saes et al. 1992). Souza and Hildred (1980) characterized the Aguapeí Group as a thick sequence of siliciclastic rocks composed, from bottom to top, of the Fortuna, Vale da Promissão and Morro Cristalina formations. The Fortuna Formation shows thick packages of oligomictic conglomerates and quartz sandstones with interbedded metasiltite/metapelite deposited in a shallow sea environment. The Vale da Promissão Formation displays a transitional interfingered contact with the unit underlying and comprises a sequence dominated by metapsamites, metapelites and rare metarenites deposited in a deep marine environment. The Morro Cristalina Formation is composed of fluvial sandstones and siltstones. The depositional age of the Aguapeí Group is estimated between 1167 $\pm 27 \mathrm{Ma}$ and $1149 \pm 7 \mathrm{Ma}$ (Santos et al. 2005).

The Aguapeí Group overlies the Rio Alegre plutono-volcanic rocks, occurring discontinuously along more than $500 \mathrm{~km}$ between the northeastern/ eastern margins of the Paraguá Block. The depocenter of the Aguapeí Group coincides with the paleo-suture previously established in the Rio Alegre terrane (Guaporé suture zone-Rizzotto and Hartmann 2012). The pronounced magnetic low that characterizes the Aguapeí Group may be partially related to a failed rift that is filled with Mesoproterozoic sediments (Fig. 3). We suggest that the tectonic evolution of the Aguapei Group was initiated by rifting that subsequently failed, allowing the development of a long-lived intracratonic sedimentary basin.

The Aguapeí Group exhibits pervasive deformation and low-grade metamorphism (e.g., Geraldes et al. 2001, Ruiz 2005) within a regional synform structure indicated by gentle folds 
(upright to northeast-dipping) and NW-trending shears. Sinistral shearing and thrusts deformed this sequence. Recrystallized mylonites yielded $\mathrm{K} / \mathrm{Ar}$ and ${ }^{40} \mathrm{Ar} /{ }^{39} \mathrm{Ar}$ mica ages between 960 and 910 Ma (e.g., Geraldes et al. 1997, Fernandes et al. 2006, Ruiz et al. 2007). Because of the occurrence side by side of folded and sheared rocks (Sunsás and Aguapeí Groups) and flat-lying and unmetamorphosed rocks (Huanchaca and Ricardo Franco ridges), Santos et al. (2002) prefer the usage of Aguapeí I for the folded and metamorphosed unit and Aguapeí II for the flat-lying cover.

\section{SUNSÁS BELT}

The sedimentary units of the Sunsás Group were deposited between 1300 and $1000 \mathrm{Ma}$ and unconformably overlie the metamorphic rocks of the basement. They were deformed together with the basement during the subsequent Sunsás Orogeny at ca. $1000 \mathrm{Ma}$ (Litherland et al. 1986).

The Sunsás Group comprises a sedimentary sequence up to $6 \mathrm{~km}$ thick, found mainly in the Serrania Sunsás, Bolivia (Litherland and Bloomfield 1981). In general, this group comprises a basal conglomerate overlain by psammitic units (arkoses, sandstones, quartzites), pelitic units (mudstones and siltstones), and a combination of feldspathic sandstones, pelites and quartzites (Berrrangé and Litherland 1982). Sedimentary structures, such as cross-beds and ripple marks, are common in the psammitic units, mainly in quartzites of the Serrania Los Tajibos. Berrrangé and Litherland (1982) suggested that the sedimentary rocks of the Sunsás Group were deposited in an alluvial to deltaic environment. Later, Saes et al. (1992) referred to the sediments as deposited in an intracontinental rift.

The upper psammitic units (Vibosi Group) of the Sunsás Group were intruded by the layered Rincón del Tigre igneous complex (Prendergast 2000), which yielded a Rb-Sr age of ca. $990 \mathrm{Ma}$. This age is similar to that obtained for the late syn- to post-tectonic
Sunsás granites (Litherland et al. 1986).

The Sunsás belt is structurally marked by upright NW-trending folds formed contemporaneously with extensive mylonitic shear zones that developed during low-to-medium grade metamorphism, active at ca. 1080-1050 Ma (Boger et al. 2005).

\section{MATERIALS AND METHODS}

The samples were crushed, milled and split into fractions for whole rock isotope geochemistry, zircon, rutile and titanite dating. Zircon, titanite and rutile were separated from twelve samples using heavy liquid and magnetic separation techniques. All rocks were investigated in thin section, and their chemical compositions were determined. Nine rock samples were analyzed by SHRIMP at the Curtin University of Technology-Australia, and three samples were analyzed by LA-MC-ICPMS. All grains used for zircon, titanite and rutile dating were imaged with backscattered electrons to determine their internal structure and the nature (igneous or metamorphic) of their growth zones. The sampling sites are shown in Figure 1, and general data for each sample (coordinates, rock name, and stratigraphic unit) are described in the next item.

The analytical procedures are described in the online edition (Appendix SA) (Supplementary material), and the isotopic data are presented in Table I.

\section{RESULTS}

NOVA BRASILÂNDIA BELT

The samples were collected along an EW belt that contains primarily mafic rocks belonging to proto-ocean, the Nova Brasilândia rift. These lithotectonic units were deformed by NW-SE $\left(\mathrm{D}_{1}\right)$ to $\mathrm{E}-\mathrm{W}\left(\mathrm{D}_{2}\right)$ transpressional phases, corresponding to a progressive thrust to transcurrent shear zones. Generally, all localities preserve evidence of granulite facies metamorphism associated with ductile deformation; orthopyroxene often 


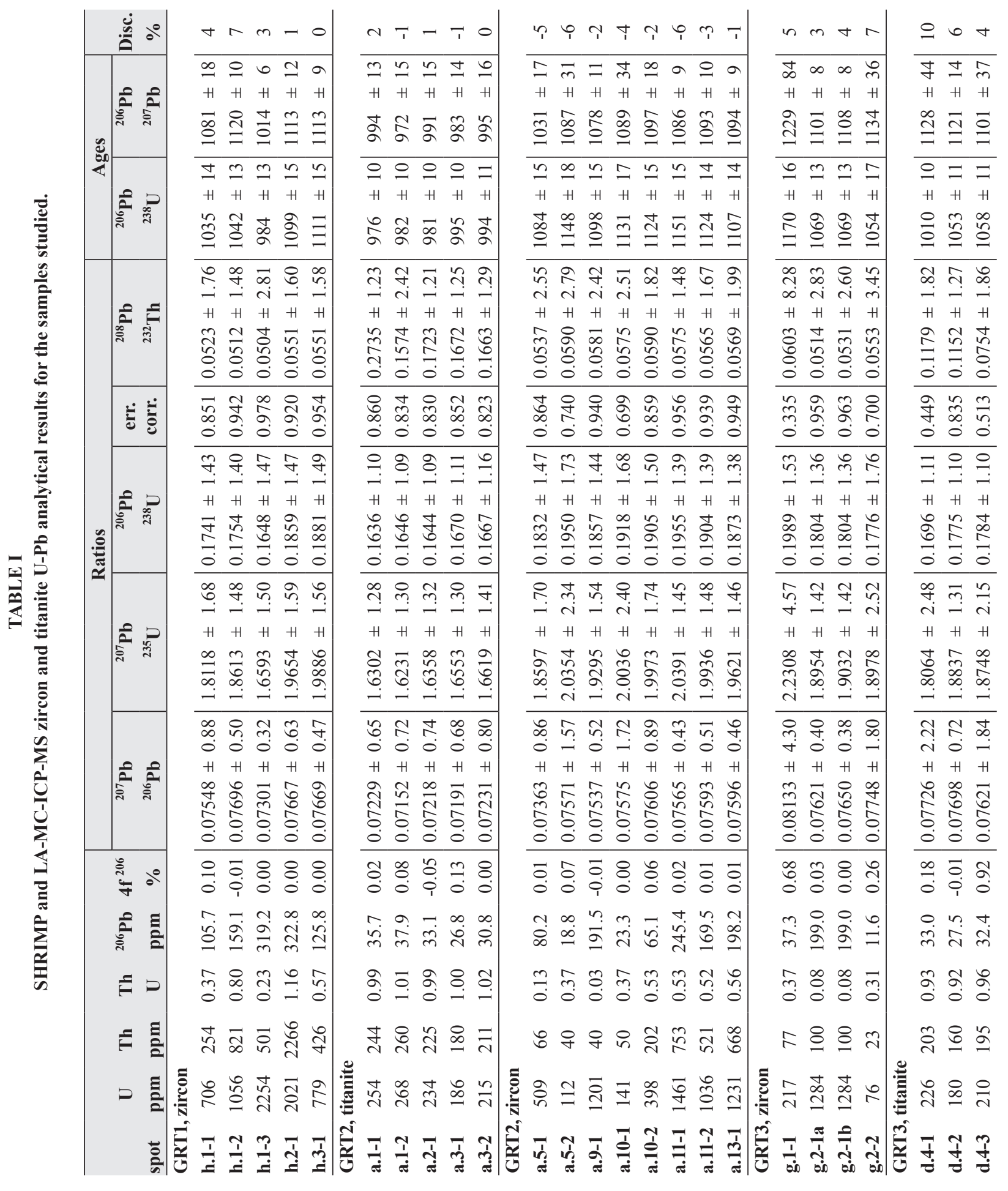




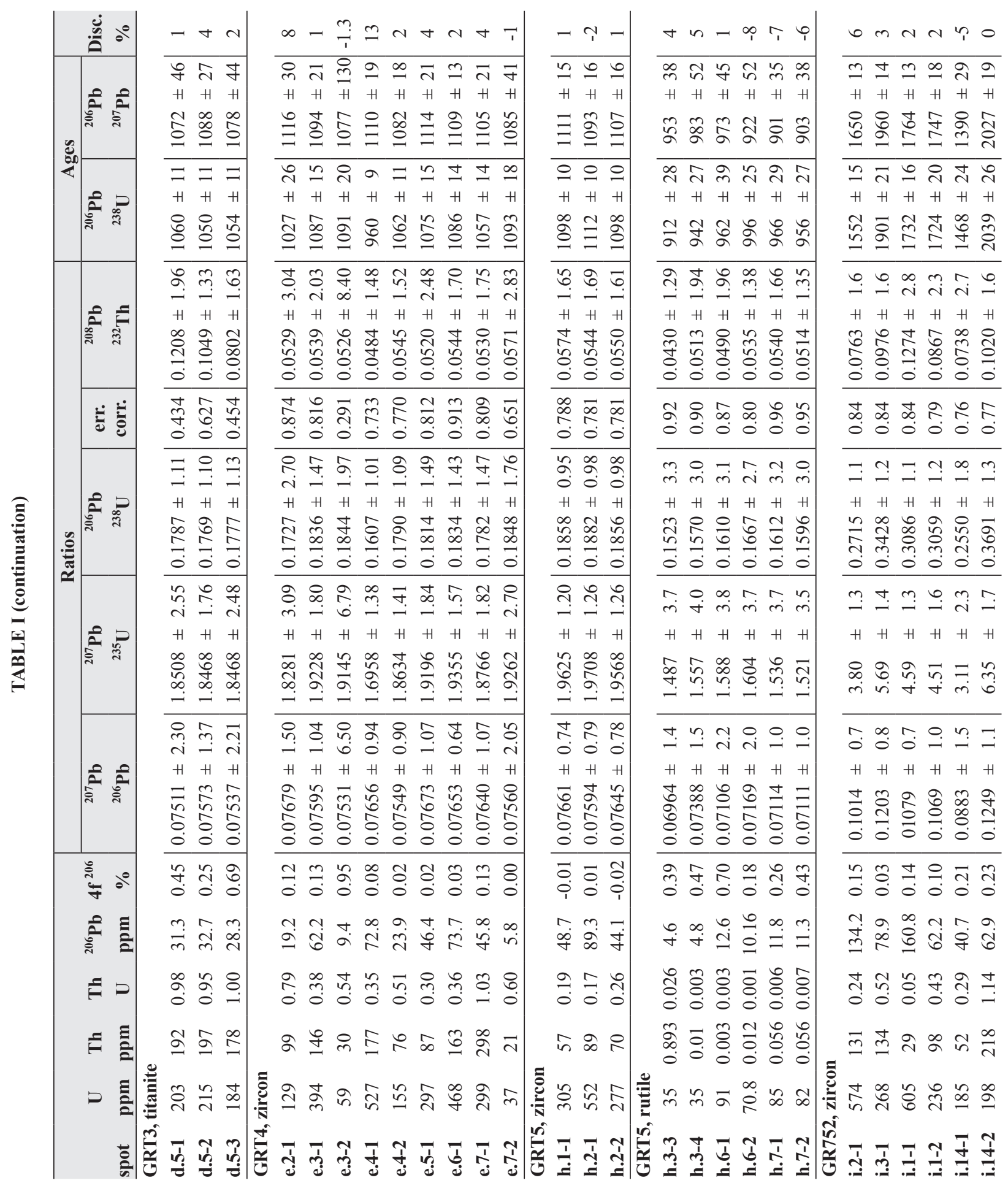




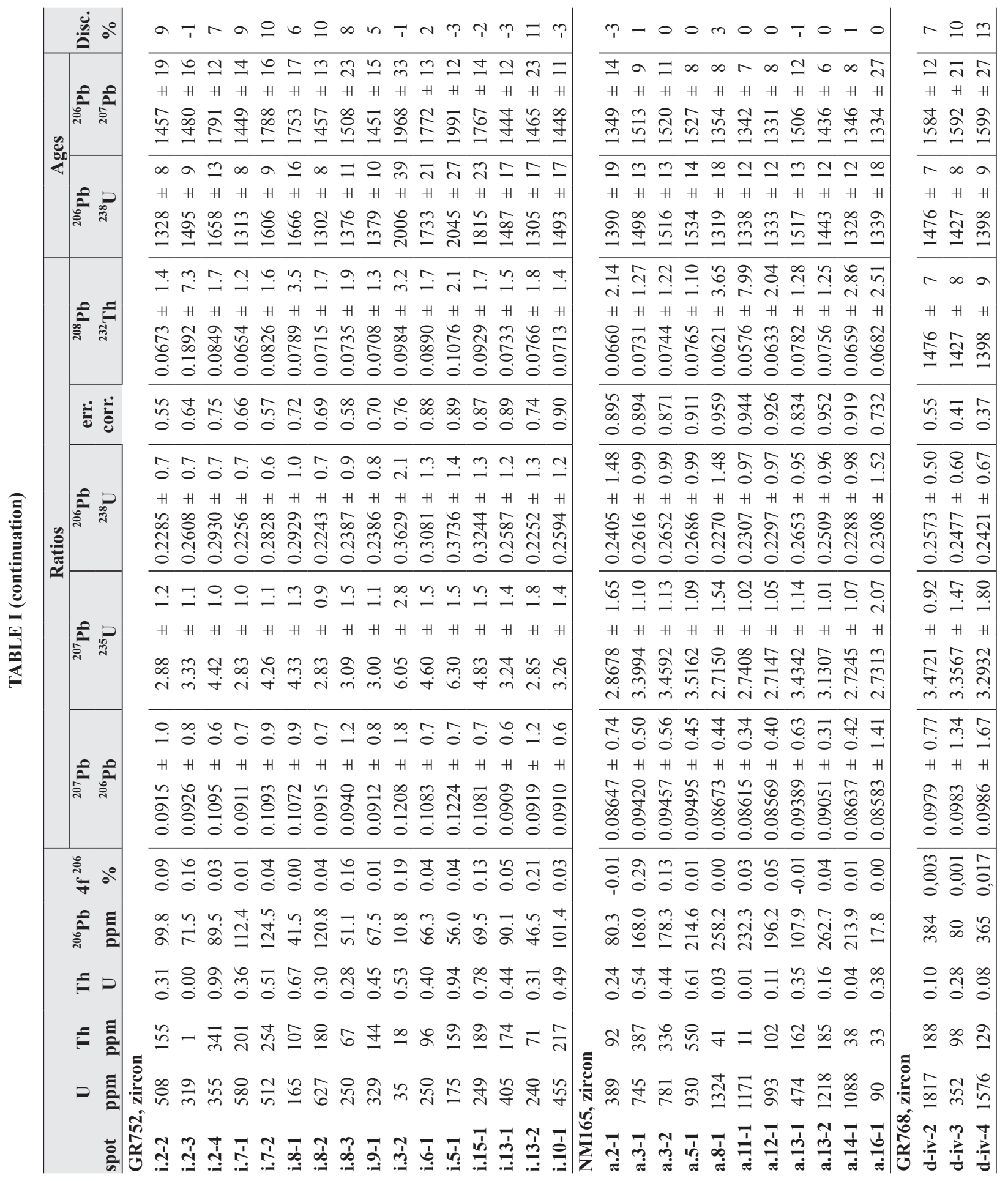




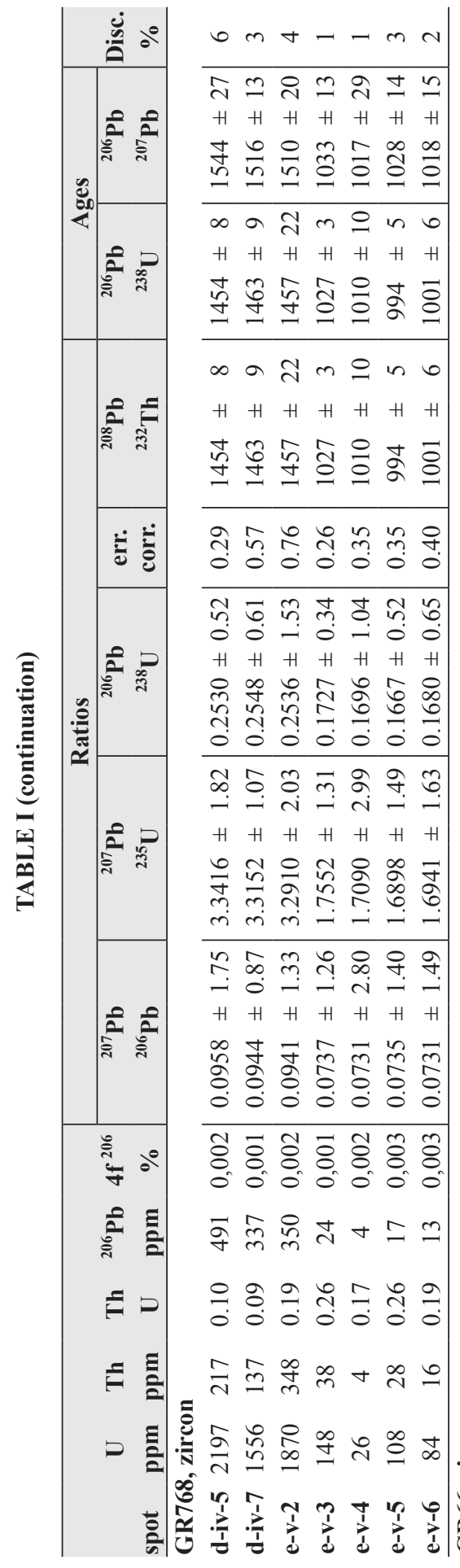

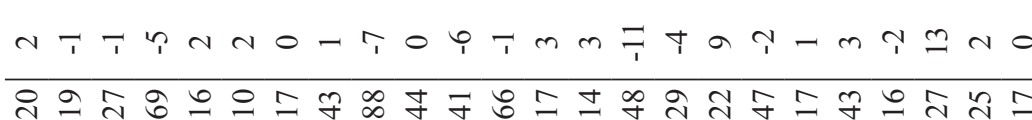
H H H H H H H H H H H H H H H H H H H H H H H H

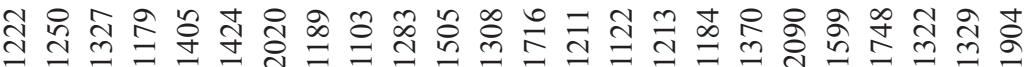

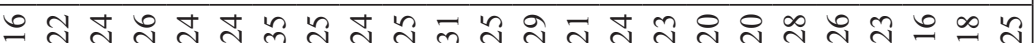
H H H H H H H H H H H H H H H H H H H H H H H H 。

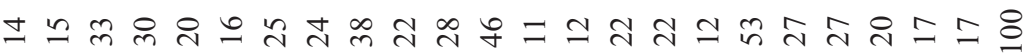
H H H H H H H H H H H H H H H H H H H H H H H H

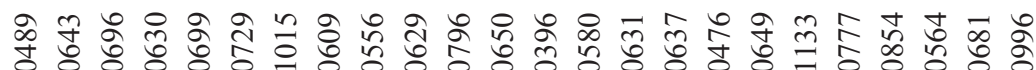

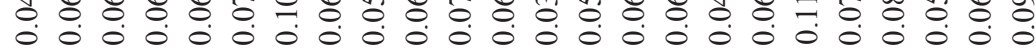
맘

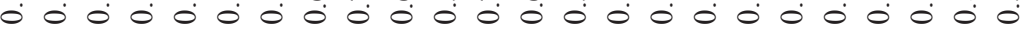

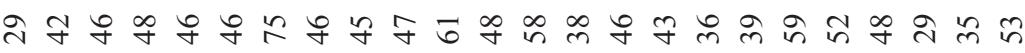
H H H H H H H H H H H H H H H H H H H H H H H H

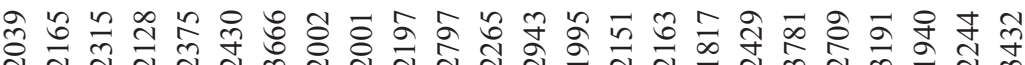

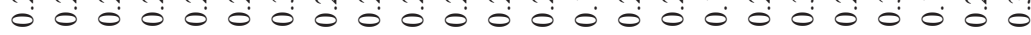

군유의 H H H H H H H H H H H H H H H H H H H H H H H H

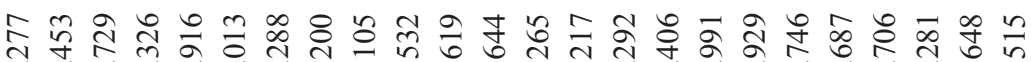

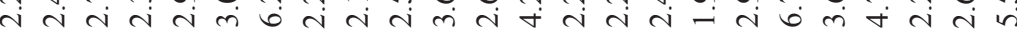

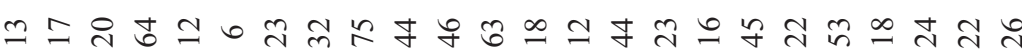
H H H H H H H H H H H H H H H H H H H H H H H H

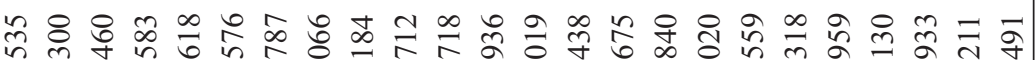

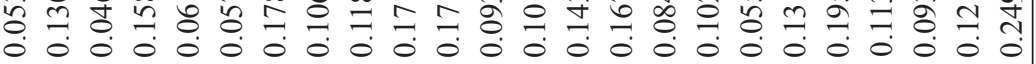

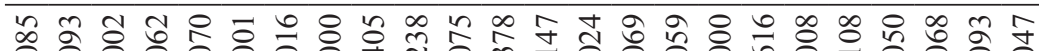

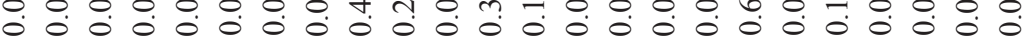

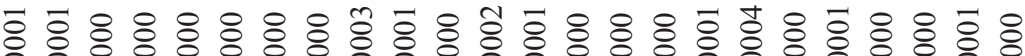

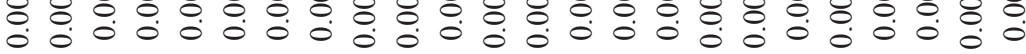

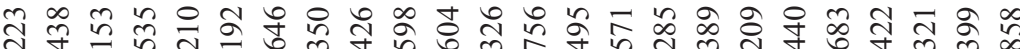

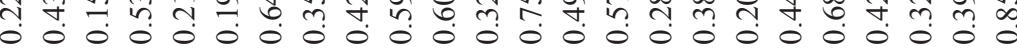
\&ळ

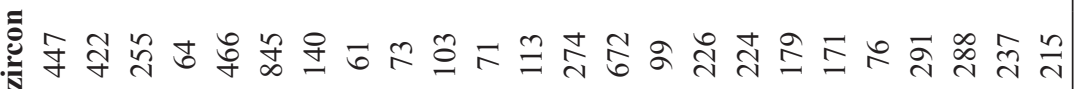

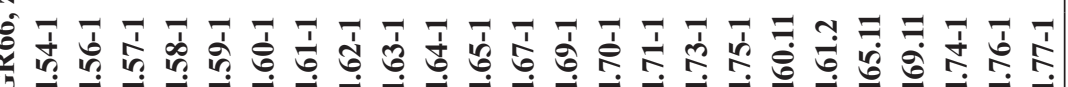


TABLE I (continuation)

\begin{tabular}{|c|c|c|c|c|c|c|c|c|c|c|}
\hline \multirow[b]{2}{*}{ spot } & \multicolumn{4}{|c|}{ Isotopic ratios . } & \multicolumn{3}{|c|}{ Ages } & \multirow[b]{2}{*}{ f206 } & \multirow[b]{2}{*}{$\begin{array}{c}\text { Dis } \\
\%\end{array}$} & \multirow[b]{2}{*}{$\begin{array}{c}{ }^{232} \mathrm{Th} \\
{ }^{238} \mathrm{U}\end{array}$} \\
\hline & ${ }^{207} \mathrm{~Pb}$. & ${ }^{206} \mathrm{~Pb}$. & Rho & ${ }^{207} \mathrm{~Pb}$ & ${ }^{238} \mathrm{~Pb}$. & ${ }^{207} \mathrm{~Pb}$. & ${ }^{2006} \mathrm{~Pb}$ & & & \\
\hline \multicolumn{11}{|c|}{ NM182, zircon } \\
\hline $\mathrm{cv}-01$ & $2.53454 \pm 1.41$ & $0.21420 \pm 0.52$ & 0.37 & $0.08582 \pm 1.31$ & $1251 \pm 7$ & $1282 \pm 18$ & $1334 \pm 18$ & 0.0004 & 6 & 0.38 \\
\hline cv-02 & $3.17845 \pm 1.40$ & $0.24659 \pm 0.45$ & 0.32 & $0.09348 \pm 1.32$ & $1421 \pm 6$ & $1452 \pm 20$ & $1498 \pm 20$ & 0.0001 & 5 & 0.43 \\
\hline cv-04 & $5.97356 \pm 2.94$ & $0.35067 \pm 0.32$ & 0.11 & $0.12355 \pm 2.93$ & $1938 \pm 6$ & $1972 \pm 58$ & $2008 \pm 59$ & 0.0000 & 4 & 0.50 \\
\hline cv-39 & $3.46876 \pm 1.21$ & $0.26243 \pm 0.64$ & 0.53 & $0.09586 \pm 1.02$ & $1502 \pm 10$ & $1520 \pm 18$ & $1545 \pm 16$ & 0.0006 & 3 & 0.20 \\
\hline cv-40 & $3.40291 \pm 0.87$ & $0.26381 \pm 0.46$ & 0.53 & $0.09355 \pm 0.74$ & $1509 \pm 7$ & $1505 \pm 13$ & $1499 \pm 11$ & 0.0001 & -1 & 0.35 \\
\hline cv-42 & $3.44029 \pm 0.94$ & $0.26608 \pm 0.56$ & 0.59 & $0.09377 \pm 0.75$ & $1521 \pm 8$ & $1514 \pm 14$ & $1504 \pm 11$ & 0.0001 & -1 & 0.50 \\
\hline cv-43 & $4.03463 \pm 1.16$ & $0.29477 \pm 0.81$ & 0.70 & $0.09927 \pm 0.83$ & $1665 \pm 13$ & $1641 \pm 19$ & $1610 \pm 13$ & 0.0002 & -3 & 0.69 \\
\hline cv-48 & $3.63067 \pm 1.76$ & $0.27049 \pm 0.77$ & 0.44 & $0.09735 \pm 1.59$ & $1543 \pm 12$ & $1556 \pm 27$ & $1574 \pm 25$ & 0.0006 & 2 & 0.72 \\
\hline cv-51 & $3.49946 \pm 1.24$ & $0.27216 \pm 0.95$ & 0.77 & $0.09325 \pm 0.79$ & $1552 \pm 15$ & $1527 \pm 19$ & $1493 \pm 12$ & 0.0001 & -4 & 0.34 \\
\hline cv-56 & $3.47862 \pm 1.01$ & $0.26923 \pm 0.54$ & 0.53 & $0.09371 \pm 0.86$ & $1537 \pm 8$ & $1522 \pm 15$ & $1502 \pm 13$ & 0.0008 & -2 & 0.34 \\
\hline
\end{tabular}

\section{GR336, zircon}

\begin{tabular}{|c|c|c|c|c|c|c|c|c|c|c|}
\hline ii-1 & $39949 \pm 1.13$ & $26236 \pm 0.76$ & 0.68 & $09397 \pm 0.83$ & $502 \pm 11$ & $504 \pm 17$ & $1508 \pm 12$ & 0.0003 & 0 & .30 \\
\hline$-\mathrm{ii}-3$ & $48677 \pm 0.95$ & $.26728 \pm 0.72$ & 0.76 & $09462 \pm 0.62$ & $1527 \pm 11$ & $1524 \pm 14$ & $1520 \pm 9$ & 0.0003 & 0 & 25 \\
\hline -ii-5 & $3.55896 \pm 1.91$ & $0.26826 \pm 1.28$ & 0.67 & $.09622 \pm 1.42$ & $1532 \pm 20$ & $1540 \pm 29$ & $1552 \pm 22$ & 0.0014 & 1 & 0.51 \\
\hline ii-6 & $2.84822 \pm 1.15$ & $0.23945 \pm 0.78$ & 0.68 & $08627 \pm 0.84$ & $1384 \pm 11$ & $1368 \pm 16$ & $1344 \pm 11$ & 0.0001 & -3 & 32 \\
\hline ii-7 & $1.66614 \pm 0.98$ & $0.16179 \pm 0.63$ & 0.64 & \pm 0.75 & $967 \pm 6$ & $996 \pm 10$ & $1060 \pm 8$ & 001 & 9 & .06 \\
\hline ii-2 & $76130 \pm 1.34$ & $1 \pm 0.77$ & 0.58 & .09 & $342 \pm 10$ & $1345 \pm 18$ & $1349 \pm 15$ & 0.0005 & 1 & 33 \\
\hline iii-3 & $7 \pm 1.44$ & $71 \pm 1.11$ & . & \pm 0.92 & $=15$ & $1359 \pm 20$ & $1319 \pm 12$ & 03 & -5 & 78 \\
\hline ii-6 & $78383 \pm 1.32$ & $58 \pm 0.84$ & 0.63 & .03 & $1369 \pm 11$ & $51 \pm$ & $23 \pm 14$ & 03 & -3 & 28 \\
\hline oiii7a & $52090 \pm 1.05$ & $0.27001 \pm 0.77$ & 0.73 & $.09457 \pm 0.72$ & $1541 \pm 12$ & $1532 \pm 16$ & $1520 \pm 11$ & 0.0001 & -1 & 0.35 \\
\hline iii $7 b$ & $1.68423 \pm 1.84$ & $0.16244 \pm 1.73$ & 0.94 & $7520 \pm 0.64$ & $970 \pm 17$ & $1003 \pm 18$ & $1074 \pm 7$ & 0.0001 & 10 & 0.04 \\
\hline 1 & $2.62565 \pm 1.36$ & $0.22332 \pm 0.91$ & 0.67 & $08527 \pm 1.02$ & $1299 \pm 12$ & $1308 \pm 18$ & $1322 \pm 13$ & 0.0001 & 2 & 0.44 \\
\hline 1 & $t \pm 1.09$ & \pm 0.65 & 00 & 8 & $1301 \pm 8$ & 4 & 15 & & 2 & 5 \\
\hline iv-3 & $3.03591 \pm 1.18$ & $0.24366 \pm 1.00$ & 0.85 & $7 \pm 0.62$ & $1406 \pm 14$ & $1417 \pm 17$ & $1433 \pm 9$ & 003 & 2 & 0.27 \\
\hline -iv-5 & $2.78782 \pm 1.12$ & $0.23325 \pm 0.92$ & 0.83 & $9 \pm 0.63$ & $1351 \pm 12$ & $1352 \pm$ & $1354 \pm 9$ & 0.0001 & 0 & 0.28 \\
\hline iv-7 & $2.81440 \pm 1.15$ & $23754 \pm 0.79$ & 69 & 83 & $374=$ & $359=$ & 337 & 03 & -3 & 28 \\
\hline \multicolumn{11}{|c|}{ GR345, } \\
\hline$a-i-3$ & $1.71977 \pm 1.33$ & $0.16868 \pm 0.77$ & 0.58 & \pm 1.08 & $1005 \pm 8$ & 1016 & $1040=$ & 0 & 3 & 0.74 \\
\hline$a-i-5$ & $1.76550 \pm 1.23$ & $0.17646 \pm 0.49$ & 0.40 & $.07257 \pm 1.13$ & $1048 \pm 5$ & $1033 \pm 13$ & $1002=$ & 0.0001 & -5 & 0.35 \\
\hline$a-i-7$ & $1.76088 \pm 1.26$ & $0.17620 \pm 0.74$ & 0.59 & $3 \pm 1.02$ & $1046 \pm 8$ & $1031 \pm 13$ & $999=$ & 0.0008 & -5 & 0.62 \\
\hline a-i 12 & $1.53957 \pm 1.75$ & $0.15376 \pm 0.71$ & 0.41 & $0.07262 \pm 1.60$ & $922 \pm 7$ & $946 \pm 17$ & $1003 \pm 16$ & 0.0003 & 8 & 0.46 \\
\hline a-i 13 & $1.76515 \pm 1.42$ & $0.17634 \pm 0.99$ & 0.70 & $07260 \pm 1.02$ & $1047 \pm 10$ & $1033 \pm 15$ & $1003 \pm 10$ & 0.0002 & -4 & 0.75 \\
\hline a-i 16 & $1.72609 \pm 1.59$ & $0.17265 \pm 0.83$ & 0.5 & $.07251 \pm 1.36$ & $1027 \pm 8$ & $1018 \pm 16$ & $1000 \pm 14$ & 0.0009 & -3 & 0.50 \\
\hline a-i 25 & $1.83594 \pm 1.54$ & $0.17989 \pm 1.12$ & 0.73 & $0.07402 \pm 1.06$ & $1066 \pm 12$ & $1058 \pm 16$ & $1042 \pm 11$ & 0.0144 & -2 & 0.51 \\
\hline a-i 28 & $1.74057 \pm 1.57$ & $0.17504 \pm 0.93$ & 0.59 & $0.07212 \pm 1.27$ & $1040 \pm 10$ & $1024 \pm 16$ & $989 \pm 13$ & 0.0001 & -5 & 0.50 \\
\hline a-i 32 & $1.71426 \pm 1.53$ & $0.17251 \pm 0.74$ & 0.48 & $0.07207 \pm 1.34$ & $1026 \pm 8$ & $1014 \pm 16$ & $988 \pm 13$ & 0.0001 & -4 & 0.99 \\
\hline$-\mathrm{i}-34$ & $1.75302 \pm 1.37$ & $0.17414 \pm 0.75$ & 0.55 & $0.07301 \pm 1.14$ & $1035 \pm 8$ & $1028 \pm 14$ & $1014 \pm 12$ & 0.0004 & -2 & 0.75 \\
\hline
\end{tabular}

Notes: Isotopic ratios errors in \%; All $\mathrm{Pb}$ in ratios are radiogenic component. Most are corrected for ${ }^{204} \mathrm{~Pb}$ and some for ${ }^{208} \mathrm{~Pb}$ (metamorphic, Th-poor grains or rims). disc. = discordance, as $100-100\left\{\mathrm{t}\left[{ }^{206} \mathrm{~Pb} /{ }^{238} \mathrm{U}\right] / \mathrm{t}\left[{ }^{207} \mathrm{~Pb} /{ }^{206} \mathrm{~Pb}\right]\right\}$; f206 $=\left(\mathrm{common}{ }^{206} \mathrm{~Pb}\right) /$ (total measured ${ }^{206} \mathrm{~Pb}$ ) based on measured ${ }^{204} \mathrm{~Pb}$. Uncertainties are $1 \sigma$. 
has an elongated granoblastic texture. However, later hydrous retrogression is widespread along transcurrent shear zone, and the orthopyroxene shows various degrees of alteration to amphibolite. The analyzed samples show minimal retrogression.

Sample GRT-01 (S 11'57'49"/W 6144'58”) is a dark gray, coarse-grained mafic granulite with granoblastic texture. It is fine-grained within mylonitic zones and displays several millimeterto-centimeter-sized veinlets of amphibole that are randomly oriented and associated with sulfides, resulting from retrogressive amphibolite facies conditions. Their mylonitic foliation trends $\mathrm{N} 60^{\circ} \mathrm{W}$; $30^{\circ} \mathrm{NE}$, with mineral lineation at $35^{\circ} ; \mathrm{N} 30^{\circ} \mathrm{W}$.

Zircon grains from this sample are generally of 80 to $120 \mu \mathrm{m}$ in size with partly rounded or broken terminations and are generally structureless or patchily zoned. Zircon grains reveal internal features characteristic of the solid state recrystallization, even on grains from rocks in which igneous textures are preserved. This alteration process is pervasive through the mafic rocks of the belt.

The $\mathrm{U}$ content is highly variable (706 to 2,254 ppm) as is the Th content which ranges between 254 and 2,266 ppm (Table I). From a population of 5 analyzed crystals, 4 crystals yielded suitable isotopic response, indicating the upper intercept age of $1114 \pm 5 \mathrm{Ma}$, with an MSWD of 1.09 (Fig. 4a), which is interpreted as peak metamorphism age. This age is in agreement with the age measured in the anatectic melt $(1110 \pm 8 \mathrm{Ma})$ of the northern domain of the Nova Brasilândia belt (Rizzotto 1999). However, there is one zircon (grain h.1-3) with discordant ages near $1014 \mathrm{Ma}$, which may indicate $\mathrm{Pb}$ loss due to the superimposition of a later metamorphic event.

Sample GRT-02 (S 11 $\left.{ }^{\circ} 57^{\prime} 04 " / \mathrm{W} 61^{\circ} 45^{\prime} 01^{\prime \prime}\right)$ is a banded leucocratic trondhjemite, fine- to medium-grained, and forms subconcordant lenses (ca. $300 \mathrm{~m}$ long and $50 \mathrm{~m}$ thick) intercalated with mafic granulite. It consists mainly of quartz and variably saussuritized plagioclase, with $\leq 10 \%$ interstitial mafic minerals (mostly amphibole and clinopyroxene, with titanite, magnetite and traces of zircon). Titanite crystals contain inclusions of biotite, plagioclase, quartz and epidote. Titanite crystals develop along the foliation planes characterizing synkinematic crystals. Much of the matrix titanite is aligned and concentrated in amphibole-rich bands that anastomose around granoblastic plagioclase/quartz-rich domains.

Zircon and titanite crystals were dated. Zircons grains are light tan to colorless, clear and show a varied morphology with sizes ranging from 100 $\mu \mathrm{m}$ to $350 \mu \mathrm{m}$. Elongated prisms characterize the most frequent zircon type, but ovoid habits with rounded terminations are also observed. The zircon crystals reveal the most varied internal features, with a disruption of concentric oscillatory zonation resulting in zoning irregular patches and ghost zoning. Some grains have fractured cores and homogeneous rims.

The U content of zircon varies from 509 to 1,461 ppm (Table I). Thirteen analyses in ten zircon grains were obtained from this sample. Eight of these analyses yielded a weighted mean ${ }^{207} \mathrm{~Pb} /{ }^{206} \mathrm{~Pb}$ age of $1089 \pm 9$ Ma (MSWD =1.5 - Fig. 4b), which is interpreted as the metamorphic age of the trondhjemite. The age of metamorphism is slightly younger than that of sample GRT-01, which may be due to $\mathrm{Pb}$ loss resulting from alteration processes such as metamictization.

Light tan to dark titanite grains are subhedral to rounded and unzoned, and generally, crystals are fragmented with widths that vary from 120 to $200 \mu \mathrm{m}$. The $\mathrm{U}$ contents of the grains are generally lower than $300 \mathrm{ppm}$, and the Th content varies between 180 and $260 \mathrm{ppm}$. Regardless, the $\mathrm{Th} / \mathrm{U}$ ratios are high, and their occurrence within metamorphic bands indicates that these grains grew in a metamorphic environment.

The five analyzed grains plot on concordia (Fig. 4b), indicating a concordant age of $986 \pm 6$ Ma. The large difference between the titanite age 

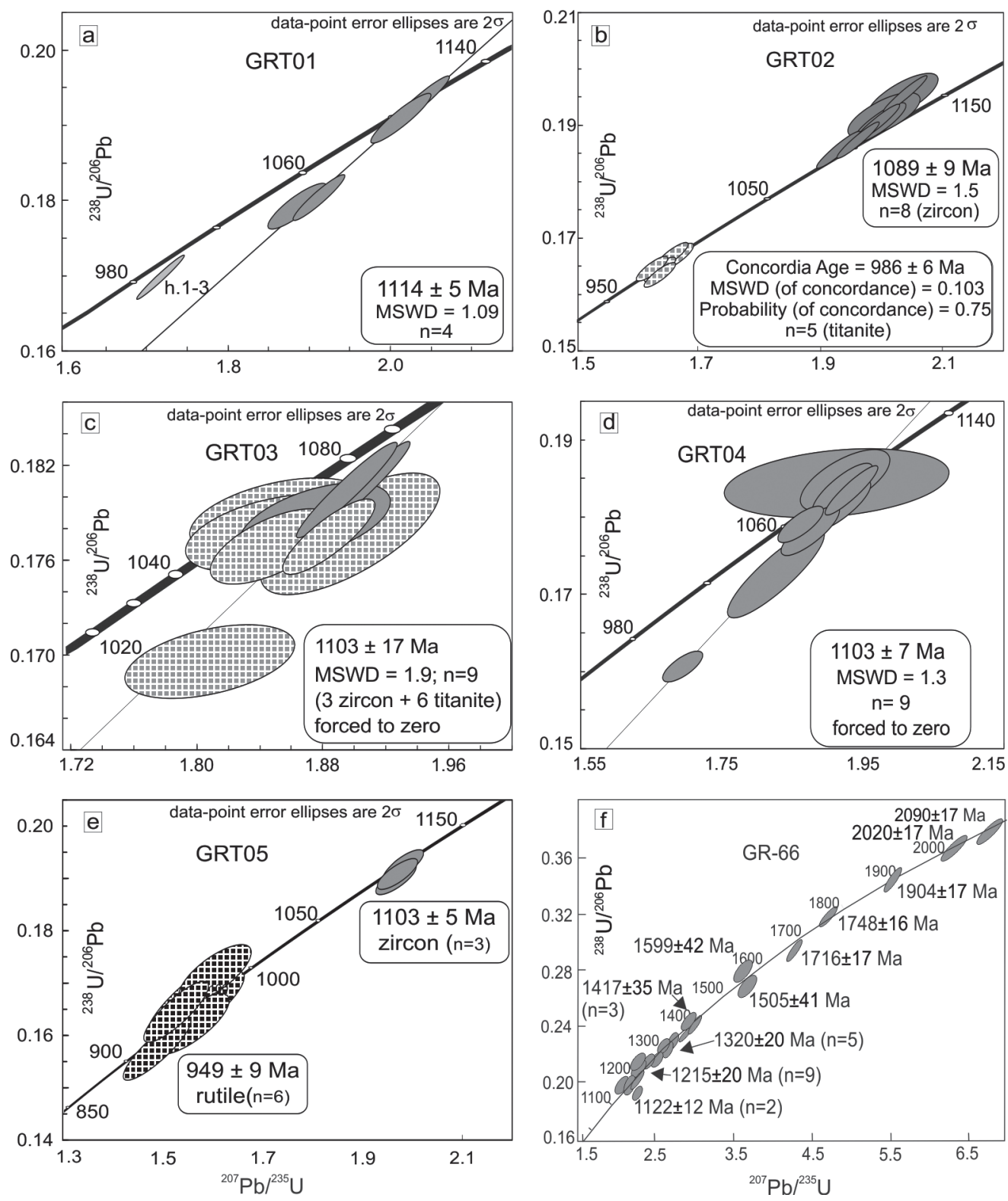

Figure 4 - Concordia diagrams of dated samples of the Nova Brasilândia belt.

and zircon age suggests that there may have been a deformation phase at $\sim 1.0 \mathrm{Ga}$. Another possibility is that titanite has a lower closure temperature than zircon, and thus, this age would represent the cooling after peak metamorphism. In this same area, Tohver et al. (2004) dated monazite crystals from a mylonitic gneiss, near GRT-01, which yielded the age of $993 \pm 11 \mathrm{Ma}$. These authors argue that monazite grew below its closure temperature through dynamic recrystallization. This interpretation is in agreement with the previous suggestion of a later phase deformation at ca. 1.0 Ga.

Sample GRT-03 (S 1153'11”/W 62²9'11”) is a light gray banded trondhjemite, mediumgrained, in decametric lenses intercalated with mafic granulites. The mineralogy and texture of this trondhjemite are similar to sample GRT-02. However, its has higher content of mafic minerals 
(amphibole and clinopyroxene) and banding defined by the preferred orientation of these minerals. The metamorphic fabrics range in intensity from a welldeveloped foliation to gneissic banding in high strain zones. Lineation is characterized by low rake angle, suggestive of a strike-slip component of the motion.

Zircon crystals are slightly elongate and exhibit stubby habit with rounded terminations, which render oval morphologies to some grains. Generally, crystals are fragmented, and their length varies between 100 and $200 \mu \mathrm{m}$. Irregular light patches and ghost zoning are also commonly observed. Four zircon grains were analyzed and show high $\mathrm{U}$ contents between 217 and 1,284 ppm, although one analysis yielded only $76 \mathrm{ppm}$. Th contents are mostly high, varying between 23 and $100 \mathrm{ppm}$. Low Th/U ratios (0.08 -Table I) indicate a correlation with light patches, suggesting that these zones are metamorphic. One zircon grain with a core with irregular concentric oscillatory zoning in the core yielded the oldest age (1229 $\mathrm{Ma}$, either magmatic or inherited. In this scenario, the mafic rocks would have assimilated zircon from an older crust, although rocks of this age not been discovered in the region.

In addition to of zircons, six titanite grains were analyzed. They are generally fragmented with various sizes and shapes, and their lengths vary between 200 and $500 \mu \mathrm{m}$. Most of the grains are unzoned or have faint, patchy zoning. Titanite crystals have U contents lower than $210 \mathrm{ppm}$, varying between 180 and $203 \mathrm{ppm}$, and have Th near $200 \mathrm{ppm}$. Combining the data from zircon and titanite, the metamorphic recrystallization in this sample is dated at $1103 \pm 17 \mathrm{Ma}$ (Fig. 4c) by nine analyses ( 3 zircon +6 titanite).

Fine-grained amphibolite (Sample GRT-04; S 11 53 '23"/W 62²9'16") of upper amphibolite facies with minor intercalations of trondhjemite dominates the central part of the mafic belt of the Nova Brasilândia proto-ocean. This sample is amphibole-rich amphibolite that partially preserves primary igneous features. In thin section, brown and clear titanite grains occur primarily in amphibole-epidote-rich domains. The plagioclase has lobate grain boundaries, often recrystallized to small subgrains, and shows evidence of strong deformation. The mineralogical and textural features suggest gabbro as the protolith.

Zircon grains this sample are colorless, clear, elongated, prismatic-to-rounded, and many contain numerous cracks. Most grains are structureless or patchily zoned. Irregular light patches occur in various parts of the crystals. The $U$ content of the zircon varies between 37 and $527 \mathrm{ppm}$, and the Th contents between 21 and $298 \mathrm{ppm}$. Nine analyses this sample yield an intercept age of $1103 \pm 7 \mathrm{Ma}$ $(M S W D=1.3$ - Fig. $4 d$ ), which is interpreted as the age of peak metamorphism. This age is the same as that obtained from sample GRT-03 described above.

A coarse-grained amphibolite was collected at the westernmost part of the mafic belt of the Nova Brasilândia rift, near the contact with a porphyroblastic milonitic granite. Sample GRT-05 (S $\left.11^{\circ} 57^{\prime} 08^{\prime \prime} / \mathrm{W} 63^{\circ} 05^{\prime} 57^{\prime \prime}\right)$ has partially preserved igneous texture and zones with well-developed mylonitic foliation. The mylonitic fabric is defined by a preferred orientation of amphibole or by subcentimeter-to-centimeter scale titanite-ilmenite veinlets. Their mylonitic foliation shows a W-E structural trend.

Zircon and rutile crystals were analyzed. Zircon crystals are weakly zoned (ghost zoning) and generally 100 to $200 \mu \mathrm{m}$ in size. They exhibit stubby habit with rounded terminations, which provide oval-to-rounded morphologies to some grains. U contents range from 277 to $552 \mathrm{ppm}$, and Th contents are more uniform and vary from 57 to $89 \mathrm{ppm}$. U-Pb isotopic analyses of three zircon grains yield an average ${ }^{207} \mathrm{~Pb} /{ }^{206} \mathrm{~Pb}$ age of $1103 \pm 5 \mathrm{Ma}$ (Fig. 4e), which we interpret to be a metamorphic recrystallization age.

Rutile grains show an external morphology that varies from prismatic to slightly rounded, and 
these grains are 100-250 $\mu \mathrm{m}$ long. Six grains were dated and yielded $\mathrm{a}^{207} \mathrm{~Pb} /{ }^{206} \mathrm{~Pb}$ concordia age of 949 \pm 9 Ma (Fig. 4e). Taking into account the analytical uncertainty, this age is similar to the titanite age of sample GRT-02. Generally, the U/Pb ages for rutile are younger than the age of peak metamorphism and younger than the $\mathrm{U} / \mathrm{Pb}$ ages for zircon, titanite and monazite (Mezger et al. 1989). This result suggests that the rutile ages reflect cooling below closure temperatures. However, there is a large difference between the peak metamorphic age recorded by zircon $(\sim 1100 \mathrm{Ma})$ and the age of metamorphic rutile ( $\sim 950 \mathrm{Ma})$. Another possible scenario is that the metamorphic rutile grew below its closure temperature through dynamic recrystallization, promoted by a later phase of deformation at ca. $1.0 \mathrm{Ga}$. This later phase of deformation is related to the Rio Branco transcurrent shear zone development in low amphibolite facies metamorphic conditions (Rizzotto 1999).

The sample GR-66 (S 1143'33"'/W 6209'10") was previously dated by Rizzotto (1999) and has now been reprocessed. It is a fine-grained banded paragneiss, with well-defined felsic bands composed of quartz and plagioclase and mafic bands of biotite. The mineral assemblage is in metamorphic equilibrium compatible with upper amphibolite facies conditions.

Twenty-four grains from this sample were analyzed (Table I). The largest population ( 9 grains) yield an age of $1215 \pm 20 \mathrm{Ma}$. Five grains yield older ages of $1320 \pm 20 \mathrm{Ma}$, while a group of three crystals has an age of $1417 \pm 35 \mathrm{Ma}$. A younger population with an age of $1122 \pm 12 \mathrm{Ma}$ was also obtained (2 grains). The remaining data yield a spread of ages between 2090 and $1505 \mathrm{Ma}$ (Fig. 4f). These results suggest that the protolith of the Nova Brasilândia paragneiss was derived from a Paleoproterozoic/ Mesoproterozoic mixed source. These data further suggest that the sedimentary protolith of the Nova Brasilândia Group was not deposited prior to 1122 $\mathrm{Ma}$, the youngest age obtained from the population of detrital zircon grains.
Therefore, all of the ages reported above are equivalent, within error ranges, and represent the timing of peak metamorphism $(\sim 1104 \mathrm{Ma})$ after the late Mesoproterozoic intraplate rifting (1150$1122 \mathrm{Ma})$.

\section{AguAPEÍ BeLt}

The sampled area is the most northwestern region of the belt, near the southwestern boundary of the Parecis Basin (Figs. 1 and 2). This area consists of a repetitive, intercalated sequence of pelitic and quartzose layers, suggesting a turbiditic sequence. In spite of the midto-low metamorphic grade of this area (greenschist to lower amphibolite facies), $\mathrm{S}_{0}$ bedding is locally preserved and still distinguishable in some outcrops. The metasedimentary rocks of the area investigated in this work are structurally and lithologically distinct from the mature, continental sediments of the Aguapei Group (e.g., Souza and Hildred 1980, Saes 1999). However, we propose that these metasedimentary rocks (sand-silt rhythmites) form part of the basal unit of the Aguapeí Group. Accordingly, this metasedimentary package is very similar structurally and lithologically to the metasedimentary rocks of the Nova Brasilândia Group.

Sample NM-165 (S 13²5'39'/W 60'15'20") is an aluminous metapsammite, which is interbedded with metapelitic layers, suggesting a turbiditic environment. It shows pervasive symmetrical folds with mainly quartz, biotite and garnet and fine veinlets of quartz along the axial plane.

Zircon grains from this sample vary in size with partly rounded or have broken terminations, and vary in size from $100-300 \mu \mathrm{m}$ with an aspect ratio of 3:1 to 2:1. Although magmatic euhedral faces are present in some crystals, rounding is a common feature in many crystals, and all are detrital. The main population $(n=6)$ has an age in the 1331-1354 Ma range (Table I and Fig. 5a) interpreted to have been derived from rocks of the Alto Guaporé belt, such as the granitoids of the Igarapé Enganado and Alto Escondido suites (Rizzotto 2010). Four grains 

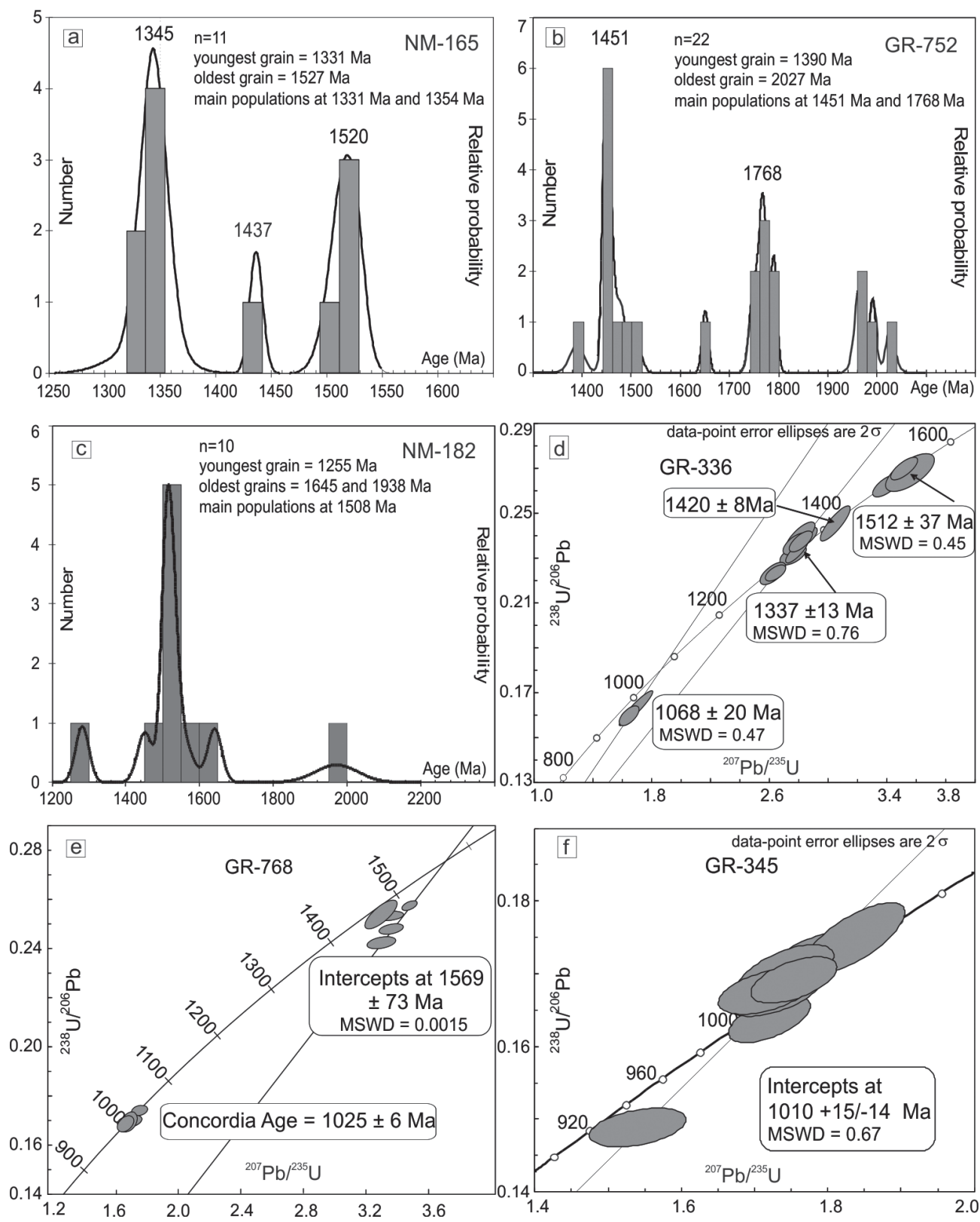

Figure 5 - U-Pb concordia plots and relative probability plots of zircon ages from samples of the Aguapeí belt and intrusives rocks.

have ages between 1506 and $1527 \mathrm{Ma}$, derived from rocks of the Rio Alegre terrane. One grain has an age of $1436 \pm 6 \mathrm{Ma}$ and derived from the Trincheira complex. The youngest zircon yielded an age of 1331 $8 \mathrm{Ma}$ (Table I), which is interpreted as the maximum sedimentation age of the sedimentary protolith.

Sample GR-752 (S 1325'26"/W 60¹5'40") is a banded phyllite interbedded with quartzite layers.
It consists of quartz, biotite and garnet aggregates arranged along a well-developed vertical foliation. Many ptigmatic folds consists mainly of quartz, and the layers are cross-cut by an dense network of quartz veins. Folds axis are consistent with the mineral lineation at $70^{\circ} ; \mathrm{S} 80^{\circ} \mathrm{W}$.

Most zircon grains are short prisms with rounded edges and variable shapes and color and 
are all detrital. They present two main populations, 1451 and $1768 \mathrm{Ma}$; the youngest grain has an age of $1390 \mathrm{Ma}$ and the oldest grain $2027 \mathrm{Ma}$ (Fig. 5b). The ages of the most representative zircon populations $(1.45 \mathrm{Ga} ; 1.76 \mathrm{Ga})$ signify not only the different continental sedimentation sources (Leite and Saes 2003) but also the timing of the adjacent magmatic arcs (Jamari and Santa Helena magmatic arcs), which forms part of the basement in the Rondônia and Mato Grosso states of the southwestern margin of the Amazonian craton.

Sample NM-182 (S 13²6'35"/W 6009'25") is an impure quartzite (metagreywacke), which presents overturned and subvertical beds with metric to decimetric thickness and oriented banding at $\mathrm{N} 05^{\circ} \mathrm{E} / 85^{\circ} \mathrm{SE}$, although it is strongly folded in the highest strain zones. This quartzite is interbedded with thin beds of biotite-rich metamudstones (phyllites).

Most zircon grains are small $(80-120 \mu \mathrm{m})$ with rounded edges, and several types of shapes are present. The results obtained for the 10 analyzed zircon crystals (Table I) show that the quartzite has a wide range of zircon provenances (Fig. 5c). Most of the crystals ( $n=7)$ have an age of $1508 \mathrm{Ma}$ and may have been derived from rocks correlated to the Cachoeirinha orogeny (Ruiz 2005). Two grains yield older ages of 1938 and $1645 \mathrm{Ma}$ and are interpreted to have been derived from rocks constituting the basement of the Rondônia-Juruena Province. One grain has a younger age (1255 Ma), which may indicate the maximum depositional age of the protoliths of the Aguapeí belt and most likely was derived from rocks correlated to the San Andres Granite (Santos et al. 2008). This granite occurs in the easternmost part of Bolivia or the provenance is from another granitoid body within the basement of the Rondônia-Juruena Province.

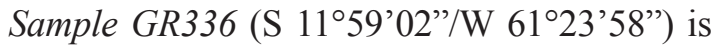
a fine-grained dark banded gneiss, which contains abundant elongated quartz nodules, in a strongly foliated matrix of quartz-plagioclase-biotite-ilmenite, including significant areas of leucosome development.
The zircon population is dominated by rounded grains, short prisms, and a very small proportion of the prismatic grains. They present variable shapes and color and are all detrital. The main population $(n=8)$ has an age of 1337 Ma (Fig. 5d) and is interpreted to have been derived from rocks of the Alto Guaporé belt, such as granitoids of the Igarapé Enganado and Alto Escondido suites. Four grains yield an age of $1512 \mathrm{Ma}$, and these grains are derived from rocks of Serra da Providência suite. One grain has an age of $1420 \mathrm{Ma}$ and may have been derived from the tonalitic rocks of the Trincheira complex. The youngest zircon grains $(n=2)$ are most likely derived from granitic leucosome that has an age of $1068 \pm 20 \mathrm{Ma}$. Considering the analytical uncertainty, this age is close to the age of the metamorphic climax of the Nova Brasilândia orogeny $(\sim 1110 \mathrm{Ma})$.

Sample GR-768 (S 1315'30"/W 60¹6'00”) is from a slightly elliptical stock that is essentially undeformed. It is a fine-grained equigranular biotite syenogranite, with an elliptical to rounded mafic autolith, an isotropic structure and is intruded into metapsammites of the Aguapeí Group. Its average composition is microcline (36\%), oligoclase (27\%), quartz $(30 \%)$, biotite $(6 \%)$, zircon, apatite and fluorite $(<1 \%)$. Zircon crystals are prismatic, with aspect ratios 1:2 to $1: 4$, and are 90-150 $\mu \mathrm{m}$ long and poorly zoned. There are two populations of zircon, zoned magmatic zircon formed at $1025 \pm 6 \mathrm{Ma}$ (date of emplacement) (Fig. 5e) and inherited grains with age of the $1569 \pm 73 \mathrm{Ma}$, which is correlated to the Serra da Providência granites. Given the posttectonic timing implied for the granite, we interpret all of the observed stages of ductile deformation to have occurred prior to $1025 \pm 6 \mathrm{Ma}$.

Sample GR 345 (S 1205'49"/W 61²5'24”) is part of small stock that occur throughout the area and as intrusions in orthogneiss of the São Felipe Suite. This unit was defined by Scandolara and Rizzotto (1998) and occurs near São Felipe city in Rondônia state. The rock is medium- to fine-grained, pink- 
colored monzogranite, with an equigranular-toinequigranular texture. This rock contains biotite and/or hornblende as mafic minerals. Centimeter- to decimeter-wide granular enclaves of granodioritic orthogneiss are commonly observed. This rock is in general massive, but has locally magmatic foliation.

Zircon crystals are subhedral, prismatic grains, clear and of good quality and are 200-250 $\mu \mathrm{m}$ long with broad concentric oscillatory zoning. Of the ten crystals analyzed, nine group tightly, and one is discordant, producing the upper intercept age of $1010 \pm 15 \mathrm{Ma}$ (MSDW=0.67) (Fig. 5f). This age is interpreted to be the crystallization age of the granite and is similar to the ages obtained in other late-to post-tectonic granites within the Nova Brasilândia-Aguapeí belt.

\section{DISCUSSION}

Main questions regarding the tectonic history and further characterization of the temporal evolution of Nova Brasilândia and Aguapeí belts: (1) Were the belts contiguous, did they form and evolve in the same interval of time, or were they geologically distinct belts? (2) Did these belts form over an already-stabilized crust (craton), or do they represent a suture zone that marks a crustal boundary in the Amazonian craton?

In light of the new geochronological data combined with field data, we suggest a geographical and lithotectonic connection between the Nova Brasilândia and Aguapeí metasedimentary belts. The two belts evolved together and were generated by the reactivation of the Guapore paleo-suture (Rizzotto and Hartmann 2012, Rizzotto et al. 2013), positioned between the Amazonian craton in the north and the Paraguá Block in the south.

The belts extend up to $900 \mathrm{~km}$ inside the cratonic area in SW Amazonian craton (Fig. 1), and their curved shapes depict the ancient Guaporé suture zone.

The Nova Brasilândia belt records the processes of sedimentation, bimodal magmatism and highgrade metamorphism in a rift-basin environment during a very short time interval from 1122 to 1100 Ma. The orogeny lasted ca. 22 million years from the initial opening of the rift to the final shortening. The youngest zircon group (sample GR-66; $1122 \mathrm{Ma}-$ Fig. 4) of the Nova Brasilândia turbiditic deposits marks the opening of the rift basin, whereas the anatectic melt leucogranitic (sample GR-20; $1110 \pm 8$ $\mathrm{Ma}$ ) locally derived from the fusion of the turbidites, indicates the age of peak metamorphism and the closure of basin (Rizzotto 1999). Accordingly, Tohver et al. (2004), using the U-Pb TIMS method, investigated monazite of the Nova Brasilândia metaturbidite, located near sample GR-20, which yielded an age of $1096 \pm 5 \mathrm{Ma}$.

The proto-oceanic-rift phase is marked by the emplacement of gabbros and trondhjemites prior to $1110 \mathrm{Ma}$, corresponding to the age of the peak metamorphism affecting these rocks, according to the results obtained from samples GRT-01 to GRT-05.

The Aguapeí belt in turn presents a wider age range, representating the beginning of sedimentation, but shows strong similarities between the ages of the main sources of deposition and the maximum age of sedimentary protholiths when compared with the protolith Nova Brasilândia belt. According to Santos et al. (2005), the deposition of the lower Aguapeí Group (Fortuna Formation) occurred between $1167 \pm 27 \mathrm{Ma}$ and $1149 \pm 7 \mathrm{Ma}$. These authors argue that, considering the uncertainties in these ages, the deposition of the sediments of the Fortuna Formation occurred over a period of 46 (maximum) to $12 \mathrm{Ma}$ (minimum). This period is roughly in accordance with the interval associated with the opening and closure of the Nova Brasilândia rift, as noted above. Table II shows the main populations of zircon analyzed to date, in this paper and from previous work.

In the northernmost portion of the Aguapeí belt, the sedimentary rocks are characterized by a gneissic foliation with lower-to-middle amphibolite facies metamorphism and a tight style of folding, and their protoliths are greywackes of the turbiditic 
TABLE II

Summary of U-Pb detrital zircon data of the Nova Brasilândia and Aguapeí Groups.

\begin{tabular}{|c|c|c|c|c|c|}
\hline Sample & Rock & Method & Zircon population (* xenotime) & $\begin{array}{l}\text { Younger Zircon } \\
\text { (m.a) }\end{array}$ & References \\
\hline NM-165 & Meta-psammite & $\mathrm{U} / \mathrm{Pb}$ (shrimp) & $\begin{array}{c}1331,1334,1342,1346,1349,1354 \\
1436,1506,1513,1520,1527\end{array}$ & $1331 \pm 8$ & This work \\
\hline GR-752 & phyllite banded & $\mathrm{U} / \mathrm{Pb}$ TIMS & $\begin{array}{l}1390,1444,1448,1449,1451,1457,1465 \\
1480,1508,1650,1747,1753,1764,1767 \\
1772,1788,1791,19601968,1991,2027\end{array}$ & $1390 \pm 29$ & This work \\
\hline NM-182 & quartzite & $\mathrm{U} / \mathrm{Pb} \mathrm{TIMS}$ & $\begin{array}{c}1334,1493,1498,1499,1502,1504 \\
1545,15741610,2008\end{array}$ & $1255 \pm 7$ & This work \\
\hline AS- 88 & Meta-siltstone & $\mathrm{U} / \mathrm{Pb}$ TIMS & $1366,1447,151,1617,1658,1780,1894$ & $1299 \pm 25$ & Souza 2011 \\
\hline AS-28 & muscovite schist & $\mathrm{U} / \mathrm{Pb}$ TIMS & $\begin{array}{l}1333,1411,1521,1533 \\
1604,1607,1644,1816\end{array}$ & $1333 \pm 22$ & Souza 2011 \\
\hline CL-1 & Conglomerate & $\mathrm{Pb} / \mathrm{Pb}$ & $\begin{array}{l}1389,1397,1432,1437,1442,1496 \\
1450,1461,1463,1489,1499,1507\end{array}$ & $1319 \pm 36$ & $\begin{array}{l}\text { Leite and } \\
\text { Saes } 2003\end{array}$ \\
\hline MT-1 & quartzite & $\mathrm{U} / \mathrm{Pb}$ (shrimp) & $1453,1420,1350,1327,1271,1231$ & $1231 \pm 14$ & $\begin{array}{l}\text { Santos et } \\
\text { al. } 2001\end{array}$ \\
\hline $\mathrm{JO}-02$ & sandstone & $\mathrm{U} / \mathrm{Pb}$ (shrimp) & $1145^{*}, 1153^{*}$ & 1167 and $1149^{*}$ & $\begin{array}{l}\text { Santos et } \\
\text { al. } 2005\end{array}$ \\
\hline GR-66 & paragneiss & $\mathrm{U} / \mathrm{Pb}$ (shrimp) & $\begin{array}{l}1215,1320,1417,1505,1599 \\
1716,1748,1904,2020,2090\end{array}$ & $1122 \pm 12$ & This work \\
\hline
\end{tabular}

environment. Deep-sea turbiditic deposits were also described by Saes (1999) in the Santo Corazón region, where a deep marine turbiditic deposit that comprises deformed immature sedimentary rocks has been deposited into the central rift zone.

These geological features, except for the metamorphic grade, are also found in metaturbidites of the Nova Brasilândia Group (Rizzotto 1999). On the eastern margin of the Serra da Borda, the central portion of the Aguapeí belt, metapelites of the low Fortuna Formation (Souza 2011) have the same structural and lithological characteristics of the northern portion of the Aguapeí belt and have similar detrital zircon ages (Table II). These sedimentary sequences could represent the same lithotectonics unit with little differences in the degrees of deformation and metamorphism and deposited under the same tectonic environments, at the same time. The Aguapeí belt is confined in a narrow aborted rift, whereas the Nova Brasilândia belt was deposited in a proto-oceanic rift environment.
Additionally, providing direct evidence indicating a clear linkage between the two belts, both the Nova Brasilândia belt and Aguapeí belt were involved in a reactivation of the orogenic zone characterized by shear zone of the largescale sinistral strike-slip motion at ca. $1.0 \mathrm{Ga}$. This structure was characterized as transcurrent shear zone of the $\mathrm{D}_{2}$-phase by Rizzotto (1999), and it is recognizable on regional LANDSAT images as large-scale lineaments that extend over hundreds of kilometers. This event is recorded by zircon, titanite and rutile of the mafic rocks (GRT-01, GRT-02 and GRT-05) of the Nova Brasilândia belt (Fig. 4). Tohver et al. (2004) found similar ages in monazite (993 Ma-U/Pb) and hornblende (983 $\mathrm{Ma}-{ }^{40} \mathrm{Ar} /{ }^{39} \mathrm{Ar}$ ) from the samples collected along the transcurrent shear zone of the Nova Brasilandia belt. Similar ages were found in shear zones that affected the metasedimentary rocks of the Aguapeí Group and neighboring country rocks in the time interval between 1030 and 920 Ma (e.g., Geraldes et al. 1997, Ruiz 2005, Fernandes et al. 2006). 
The Sunsás belt, in the southeastern Bolivia shield, presents the same features and geological evolution compared with the Nova BrasilândiaAguapeí belt. Sedimentary rocks of the Sunsás Group were deposited between 1300 and 1000 Ma. Sunsás deformation show upright NW trending folds formed contemporaneously with low-tomedium grade metamorphism and is structurally well marked by mylonitic shear zones that show preferential sinistral offsets active at ca. 1080-1050 Ma. According to Boger et al. (2005), the stages of ductile deformation must have occurred prior to $1074 \mathrm{Ma}$, but tectonic reactivation along the shear zones is marked by pegmatite injections ( $997 \pm 3$ $\mathrm{Ma})$ and Au-rich zones with molibdenite that yielded a Re/Os age of $994 \pm 3$ Ma (Isla-Moreno 2009).

On the basis of our findings, we conclude that the Nova Brasilândia, Aguapeí and Sunsás metasedimentary and igneous belts were linked in the late Mesoproterozoic at ca. 1.2 Ga to 0.95 $\mathrm{Ga}$, forming what is here called the Western Amazon belt (WAB). This belt overprints the ca. 1350 crust formed by the Paraguá Block and the basement rocks of the Rondônia-Juruena Province. The main orogenic phase occurred at $1110 \mathrm{Ma}$ (peak metamorphism). The dominant metamorphic grades are high (upper amphibolite to granulite) in the northern part of the belt in Rondonia and low to medium grade (greenschist to lower amphibolite facies) in the eastern zone in Bolivia and in southern Mato Grosso (Sunsás and Aguapeí groups). Reactivation in this belt occurred through extension, uplift and exhumation after $\sim 1.0 \mathrm{Ga}$.

New field geology data coupled with robust geochronology indicate that the Paraguá Block accreted to the southwest margin of Amazonia at ca. 1.47-1.32 Ga (Rizzotto and Hartmann 2012, Rizzotto et al. 2013). Considering this scenario, we suggest that the Nova Brasilândia, Aguapeí and Sunsás groups have a within-plate origin. This scenario is supported by recent paleomagnetic results from 1.42 Ga mafic rocks of the Indiavaí Suite in Mato Grosso, that demonstrate the latitudinal proximity of the Amazonian craton north of the Nova Brasilândia belt and Guaporé suture zone and the Paraguá craton basement to the south of this suture zone by $1.42 \mathrm{Ga}$ (D'Agrella-Filho et al. 2012). Globally, the tectonic evolution of the Nova Brasilândia, Aguapeí and Sunsás Groups may be related with the final breakup of the supercontinent Columbia, which occurred at about 1.3-1.2 Ga, marked by a major episode of plate-wide extension and rifting, whit the emplacement of the gabbros, trondhjemites and volcano-sedimentary rocks. This geological evolution is similar with Laurentia in North America, where occurred the emplacement of the McKenzie, Sudbury, Seal Lake, Harp and Mealy mafic dike swarms and coeval Coppermine River basalts at about 1.3-1.2 Ga (Bartholomew and Hatcher Jr 2010).

Saes et al. (1992) interpreted the terrestrial or shallow marine to deep sedimentary rocks of the Aguapeí and Sunsás groups to be deposited in rift environment. Sedimentary rocks of the Sunsás Group comprise a basal conglomerate overlain successively by two psammitic sequences and an intervening pelitic unit that were deposited in an alluvial-to-deltaic environment (Berrangé and Litherland 1982). Subsequently, Saes et al. (1992) suggested that the deposition of the Sunsás Group has an intra-continental rift environment. These lithotectonics units differ from Nova Brasilândia Group because, in this group, igneous rocks occur temporally and genetically associated with turbidites, reflecting the deposition of these rocks in the rift depocenter. Our theory is that when the reactivation of the Guapore paleo-suture to generate the Nova Brasilândia-Aguapeí rift, the stretch rate (opening) of the rift, which is now the Nova Brasilândia rift, was high enough to generate a narrow ocean (proto-oceanic rift), while in the other two belts (Aguapeí and Sunsás), there was less opening, less sediment filling, and no ocean development (Fig. 2). 
Therefore, over the cratonic area formed by the amalgamation of the Paraguá block and Amazonian craton during the early-middle Mesoproterozoic, the Nova Brasilândia, Aguapeí and Sunsás belts would then reflect zones of intense transpression, withinplate shortening and bimodal mafic-felsic intrusion due to the collisional dynamics, localized along the axis of an intraplate Nova Brasilândia-Aguapeí rift. This tectonic cycle occurred between approximately 1150 and $1100 \mathrm{Ma}$. Deformation at this time would presumably have been driven by the collision and accretion of the Arequipa-Antofalla basement to the western margin of the Paraguá Block (Loewy et al. 2004). As reported by previously published studies, the Proterozoic tectonic evolution of the Arequipa-Antofalla basement suggests an allochthonous origin, and this microcontinent must have been part of a larger continent before $1.0 \mathrm{Ga}$. Thus, the Arequipa-Antofalla basement, a Proterozoic crustal block exposed along the modern central Andean margin, is considered to have accreted to the margin of the Amazonian craton during the Sunsás Orogeny, at approximately 1.2$0.94 \mathrm{Ga}$ (Loewy et al. 2004). According to Dalziel (1994), pervasive metamorphism at 1.2-1.0 Ga in the northern and central domains of the ArequipaAntofalla basement supports accretion of the Arequipa-Antofalla basement to the Amazonian craton during the Sunsás Orogeny. Therefore, the late Mesoproterozoic orogenic event recorded in the northern and central domains of the ArequipaAntofalla basement is coeval with events in the southwestern margin of the Amazonian craton. This indicates that the breakup of the supercontinent Columbia was followed rapidly by the assembly of another supercontinent Rodinia, which was assembled along the globally distributed Grenvillian orogens at ca. $1.0 \mathrm{Ga}$.

We partially agree with the models proposed by Loewy et al. (2004) and Boger et al. (2005) and suggest a tectonic evolution according to the framework depicted in Figure 6.

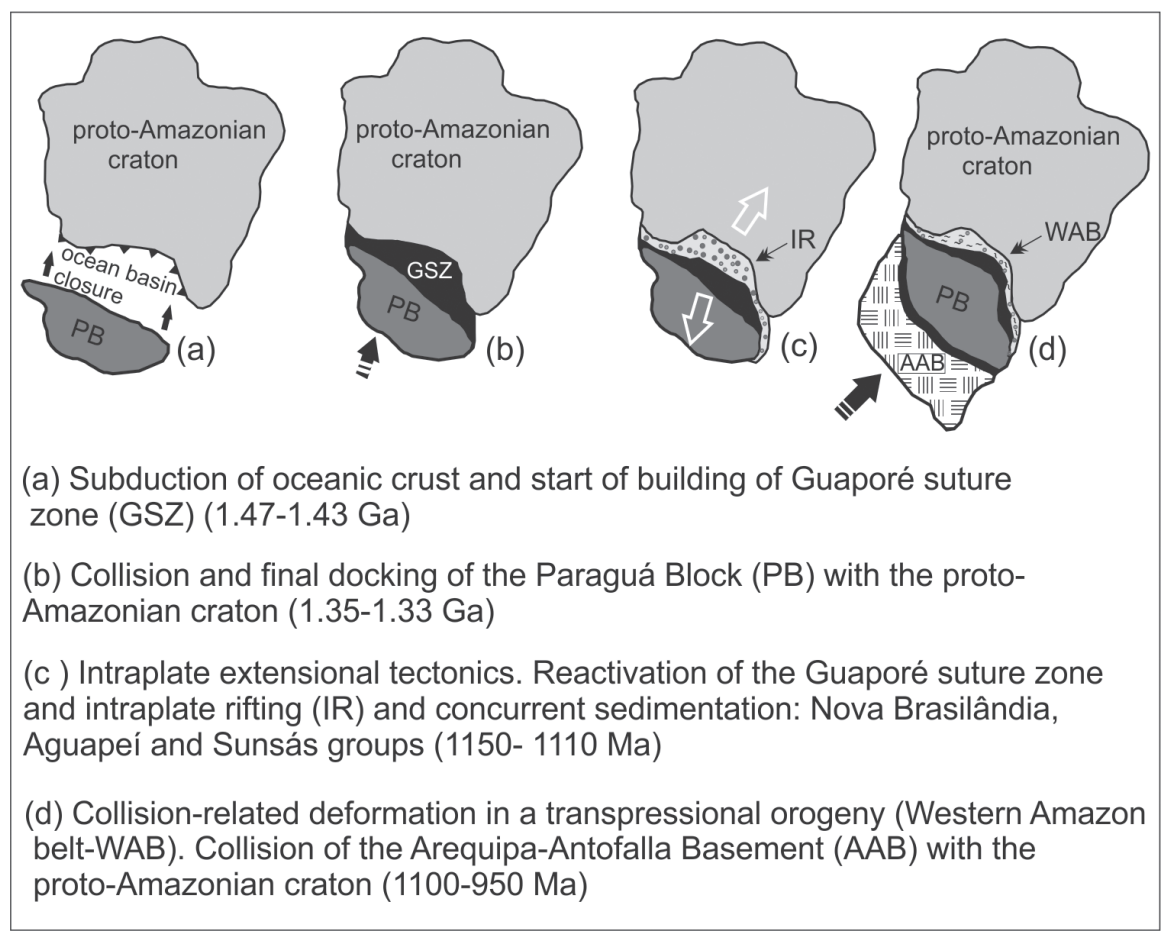

Figure 6 - Hypothetical simplified sketch, showing proposed tectonic evolution of the southwestern Amazonian craton in Mesoproterozoic time (modified of Boger et al. 2005). 


\section{CONCLUSIONS}

Zircon U-Pb geochronological data and field relationships presented in this contribution are strong evidence for the existence of a continuous intracratonic late Mesoproterozoic orogenic belt (Western Amazon belt) in the southwestern margin of the Amazonian craton.

Considering the final docking of the Paraguá Block and the proto-Amazonian craton during the middle-Mesoproterozoic time (1470-1330 Ma, Rizzotto et al. 2013), the youngest orogenic belt (WAB) of the Amazonian craton is formed by the previously defined Nova Brasilândia, Aguapeí and Sunsás belts, which became interconnected at the end of the Mesoproterozoic, and has a curvilinear shape of approximately $1,000 \mathrm{~km}$ in length. The continuity of magnetic anomalies and structural trends suggests that this belt is continuous below the Phanerozoic cover of the Parecis basin.

The opening of the rift that preceded the development of the Nova Brasilândia-Aguapeí belts originated from the reactivation of a paleo-suture (Guaporé suture zone).

We propose that the sedimentary and igneous protoliths for the three orogenic belts exposed in the southwestern margin of the Amazonian craton formed during the late Mesoproterozoic in an intracontinental rift, opening ca. $1150 \mathrm{Ma}$ and closing at $1110 \mathrm{Ma}$. Therefore, Western Amazon belt's geological history has evolved from the development of a complete Wilson cycle at ca. 40 Ma. Both the Nova Brasilândia-Aguapeí and the Sunsás belts were involved in an orogenic zone characterized by a transtensional stage that was succeeded by a transpressional regime accompanied by crustal shortening that allows the accommodation of $\mathrm{N} 45^{\circ} \mathrm{E}$ compressional stress field (Rizzotto 1999). This deformation occurred during the accretion of the Arequipa-Antofalla basement to the proto-Amazonian craton.

The latest tectonic movements, before the effective cratonization of the southeastern margin
Amazonian craton, occurred at approximately 1.0 Ga when the reactivation of the previous zone of weakness allowed the development of transcurrent zones, which favored the plutonic activity through the emplacement of the Rio Pardo granites in the Nova Brasilândia region, anorogenic plutons in the Rondônia Tin Province (Bettencout et al. 1999), posttectonic granite in Sunsás belt (Litherland et al. 1986, Isla-Moreno 2009) and in the Arequipa-Antofalla basement (Wasteneys et al. 1995, Wörner et al. 2000, Loewy et al. 2004). Soon after or during this phase, uplift, exhumation and extension culminated in the generation of intracontinental basins (e.g., Palmeiral Formation and Huanchaca Group).

\section{ACKNOWLEDGMENTS}

This work was supported by Conselho Nacional de Desenvolvimento Científico e Tecnológico (CNPq) grant 140917/2008-0. The authors thank CPRM/Geological Survey of Brazil office in Porto Velho, Rondônia, for assistance in the fieldwork and access to sample preparation. We thank also Marcos Luiz Quadros, Maria Rosalva Coelho and Pamela Emanuelle Silva for help with sample preparation. SEM images were obtained at the UWA Centre for Microscopy and Microanalysis, an Australian Microscopy \& Microanalysis Research Facility. U-Pb zircon analyses were performed on the sensitive high-resolution ion microprobes (SHRIMP II) located at the John de Laeter Centre of Mass Spectrometry, which is operated by Curtin University, the University of Western Australia and the Geological Survey of Western Australia. Constructive reviews of this manuscript by anonymous reviewer are gratefully acknowledged.

\section{RESUMO}

Novos dados de U-Pb em zircão e relações de campo, aliados aos dados de levantamento aerogeofísico permitiu-nos sugerir que os Grupos Nova Brasilândia e Aguapeí fazem parte de uma única faixa móvel 
constituída por rochas metaígneas e metassedimentares, do final do Mesoproterozóico (1150 Ma -1110 Ma). Esta história geológica é muito semelhante com a evolução intraplaca da Faixa Sunsás, no oriente Boliviano. Assim, propomos que os cinturões Nova Brasilândia, Aguapeí e Sunsás constituem uma única unidade geotectônica (aqui denominada de Faixa Móvel Amazônia Ocidental) desenvolvida no final do Mesoproterozóico, a qual instalou-se num ambiente de rift intracontinental por reativação de uma paleo-sutura (zona de sutura Guaporé). Portanto, a sua história geológica evoluiu a partir do desenvolvimento de um completo Ciclo de Wilson em cerca de 40 Ma. Globalmente, essa evolução tectônica pode estar relacionada com a fragmentação final do supercontinente Columbia. Rochas máficas e trondhjemitos da porção mais setentrional da faixa móvel forneceram idades U-Pb em zircão de $\sim 1110 \mathrm{Ma}$, as quais datam o pico do metamorfismo de alto grau e o fechamento do rift. Isso indica que a fragmentação do supercontinente Columbia foi seguida rapidamente pela montagem do supercontinente Rodínia ( 1.1-1.0 Ba) e que a Faixa Móvel Amazônia Ocidental foi construída durante a acresção do Cráton Arequipa-Antofalla ao Cráton Amazônico.

Palavras-chave: Cráton Amazônico, rift intracontinental, Mesoproterozóico, Faixa Móvel Amazônia Ocidental, geocronologia $\mathrm{U}-\mathrm{Pb}$.

\section{REFERENCES}

BARTHOLOMEW MJ AND HATCHER JR RD. 2010. The Grenville orogenic cycle of southern Laurentia: Unraveling sutures, rifts, and shear zones as potential piercing points for Amazonia. J South Am Ear Sci 29: 4-20.

BerRANGÉ JP AND Litherland M. 1982. Sinopsís de la geologia y potencial de minerales del area del Proyecto Precambrico. Boletin del Servicio Geológico de Bolivia, Informe 21, $120 \mathrm{p}$.

Bettencourt JS, Leite JR WB, Ruiz AS, Matos R, PAyolla BL AND Tosdal RM. 2010. The Rondonian-San Ignacio Province in the SW Amazonian Craton: An overview. J South Am Ear Sci 29: 28-46.

BETTENCOURT JS, TOSDAL RM, LEITE JR WBAND PAYOLLABL 1999. Mesoproterozoic rapakivi granites of the Rondônia Tin Province, southwestern border of the Amazonian Craton, Brazil-I. Reconnaissance U-Pb geochronology and regional implications. Precam Res 95: 41-67.
Boger SD, RAETZ M, GILES D, ETCHART E AND FANNING CM 2005. U-Pb age data from the Sunsas region of eastern Bolivia, evidence for the allochtonous origin of the Paraguá Block. Precam Res 139: 121-146.

Casquet C, PANKhurs, RJ, FAnNing M, Baldo E, Galindo C, RAPELA CW, CASADO JG AND DAHLQUIST JA. 2006. U-Pb SHRIMP zircon dating of Grenvillian metamorphism in Western Sierras Pampeanas (Argentina): correlation with the Arequipa-Antofalla Craton and constraints on the extent of the Precordillera Terrane. Gond Res 9(4): 524-529.

CORDANI UG, SATO K, TEIXEIRA W, TASSINARI CG AND BASEI MA. 2000. Crustal Evolution of the South American Platform. In: CORDANI UG, MILANI EJ, THOMAZ FILHO A and CAMPOS DA (Eds), Tectonic Evolution of South America, $31^{\text {st }}$. International Geological Congress, Rio de Janeiro, Brazil, p. 19-40.

D'Agrella-Filho MS, TRINDAde RIF, ELMING SA, TEIXEIRA W, Yokoyama E, Tohver E, Geraldes MC, Pacca IG, BARRos MAS AND RUIZ AS. 2012. The 1.42 Ga Indiavaí Mafic Intrusive (SW Amazonian Craton): Paleomagnetic results and implications for the Columbia supercontinent configuration. Gondwana Res 22: 956-973.

DALZIEL IW. 1994. Precambrian Scotland as a LaurentiaGondwana link: Origin and significance of cratonic promontories. Geology 22: 589-592.

Fernandes CJ, KuyumJian RM, Pulz GM, Geraldes MC AND PINHO FE. 2006. Geologia estrutural e idade ${ }^{40} \mathrm{Ar} /{ }^{39} \mathrm{Ar}$ do depósito de ouro Pau-a-Pique, Faixa Móvel Aguapeí, sudoeste do Estado de Mato Grosso. Rev Bras Geoc 36: 3-15.

Geraldes MC, Figueiredo BR, TAssinari CC AND EBERT HD. 1997. Middle Proterozoic vein-hosted gold deposits in the Pontes e Lacerda region, southwestern Amazonian Craton, Brazil. Int Geol Rev 39: 438-448.

Geraldes MC, Van Schmus WR, Condie KC, Bell S, TEIXEIRA W AND BABINSKI M. 2001. Proterozoic Geologic Evolution of the SW part of the Amazonian Craton in Mato Grosso State, Brazil. Precam Res 111: 91-128.

Isla-Moreno L. 2009. Distrito Don Mario, un deposito de $\mathrm{Au}-\mathrm{Cu}$ hidrotermal asociado a zonas de cizalla. XVIII Congreso Geológico de Bolivia, Potosi, Bolívia. Memorias del Colegio de Geólogos, p. 85-92.

JACKSON SE, PEARSON NJ, GRIFLIN WL AND BELOUSOVA EA. 2004. The application of laser ablation-inductively coupled plasma-mass spectrometry to in situ $\mathrm{U}-\mathrm{Pb}$ zircon geochronology. Chem Geol 211: 47-69.

KepPIE JD AND ORTEGA-GUTIERREZ FO. 1999. Middle American Precambrian basement: a missing piece of the reconstructed 1 Ga orogen. Geol Soc of Am, Spec Paper 336: 199-210.

Kosler J, Fonneland H, Sylvester P, Tubrett M AND PEDERSEN RB. 2002. U-Pb dating of detrital zircons for sediment provenance studies-a comparison of laser ablation ICPMS and SIMS techniques. Chem Geol 182: 605-618.

LeITE AD AND SAES GS. 2003. Geocronologia $\mathrm{Pb} / \mathrm{Pb}$ de zircões detríticos e análise estratigráfica das coberturas sedimentares proterozóicas do sudoeste do Cráton Amazonas. Rev Geol USP Série Científica 3: 113-127. 
LI ZX ET AL. 2008. Assembly, configuration, and break-up history of Rodinia: a synthesis. Precam Res 160: 179-210.

LITHERLAND M. 1986. The geology and mineral resources of the Bolivian Precambrian Shield. Overseas Memoir, British Geological Survey 9, 153 p.

Litherland M AND Bloomfield K. 1981. The Proterozoic history of eastern Bolivia. Precam Res 15: 157-179.

LOEWY S, CONNELLY JN AND DALZIEL IW. 2004. An orphaned basement block: the Arequipa-Antofalla Basement of the central Andean margin of South America. Geol Soc Am Bull 116: 171-187.

Loewy S, Connelly JN, Dalziel IW AND Gower CF. 2003. Eastern Laurentia in Rodinia: Constraints from wholerock $\mathrm{Pb}$ and $\mathrm{U}-\mathrm{Pb}$ geochronology, In: Sircombe $\mathrm{KN}$ and McElhinny MW (Eds), Orogenic belts, regional and global tectonics: A memorial volume to Chris McAulay Powell: Tectonophys 375: 169-197.

LUDWIG KR. 1999. Using ISOPLOT/Ex, $2^{\text {nd }}$ version: a geochronological toolkit for Microsoft Excel. Berkeley Geochronological Center Spec Public Ia, 47 p.

LUDWIG KR 2002. Squid 1.02, a user's manual. Berkeley Geochronological Center Special Publication 2. Berkeley, California, USA, $21 \mathrm{pp}$.

MezGer K, Hanson GN AND BoHLen SR. 1989. Highprecision $\mathrm{U}-\mathrm{Pb}$ ages of metamorphic rutile: application to the cooling history of high-grade terranes. Earth Plan Sci Lett 96: 106-118.

PRENDERGAST MD. 2000. Layering and precious metals mineralization in the Rincón del Tigre Complex, Eastern Bolivia. Econ Geol 95: 113-130.

Quadros ML, PAlmeira LC AND CASTRO CC. 2012. Geologia e Recursos Minerais da Folha Rio Machadinho (SC.20-X-C), escala 1:250.000: Sistema de Informações Geográficas-SIG: Texto Explicativo do Mapa Geológico e de Recursos Minerais da Folha Rio Machadinho. Porto Velho: CPRM, 203 p.

Rizzotto GJ. 1999. Petrologia e Geotectônica do Grupo Nova Brasilândia, Rondônia. MSc. Dissertation. Federal University of Rio Grande do Sul. Porto Alegre, Brazil. (Unpublished).

Rızzotto GJ. 2001. Reavaliação do Ciclo Orogênico Sunsas/ Aguapeí no Sudoeste do Cráton Amazônico. In: Workshop on Geology of the SW Amazonian Craton: state of the art, IGC Project 426, Extended Abstracts, p. 66-67.

Rizzotto GJ. 2010. Geologia e Recursos Minerais da Folha Pimenteiras (SD.20-X-D). Sistema de Informação Geográfica-SIG. CPRM, Rondônia, Brazil. 136 pp.

RizzotTo GJ AND DEHLER NM. 2007. Arcabouço Estrutural da Faixa Alto Guaporé e o Regime Tectônico do Ectasiano na borda SW do Craton Amazônico. XI Simpósio Nacional de Estudos Tectônicos - V International Symposium on Tectonics of the SBG, Natal, p.130-132.

Rizzotto GJ And HARTMAnN LA. 2012. Geological and geochemical evolution of the Trincheira Complex, a Mesoproterozoic ophiolite in the southwestern Amazon craton, Brazil. Lithos 148: 277-295.
Rizzotto GJ AND Quadros ML. 2007. Margem Passiva e granitos Orogênicos do Ectasiano em Rondônia. In: X Simpósio de Geologia da Amazônia. Porto Velho, CDROM.

Rizzotto GJ, Santos JOS, Hartmann LA, TOHVER E, Pimentel MM AND MCNaughton NJ. 2013. The Mesoproterozoic Guaporé suture in the SW Amazonian craton: geotectonic implications based on field geology, zircon geochronology and Nd-Sr isotopic geochemistry. J South Am Ear Sci 48: 271-295.

Rogers JJ AND SANTOSH M. 2003. Supercontinents in Earth history. Gond Res 6: 357-368.

RUIZ AS. 2005. Evolução geológica do sudoeste do Cráton Amazônico, região limítrofe Brasil-Bolívia, Mato Grosso. PhD Thesis, Universidade Estadual Paulista, Rio Claro, São Paulo, Brasil. (Unpublished).

Ruiz AS, Simões LS, ARAuJo LM, Godoy AM, MATOS JB AND SouZA MZ. 2007. Cinturão Orogênico Aguapeí (1025900 Ma): Um exemplo de Faixa Móvel Intracontinental no SW do Cráton Amazônico. In: XI Simpósio Nacional de Estudos Tectônicos, Natal. Anais, p. 116-118.

SADOWSKI GR AND BETTENCOURT JS. 1996. Mesoproterozoic tectonic correlations between eastern Laurentia and western border of the Amazon Craton. Precam Res 76: 213-227.

SAES GS. 1999. Evolução tectônica e paleogeográfica do Aulacógeno Aguapeí (1.2-1.0 Ga) e dos terrenos do seu embasamento na porção sul do Craton Amazônico. Tese de Doutorado, Instituto de Geociências, Universidade de São Paulo, São Paulo, Brasil, p. 135. (Unpublished).

SAes GS, Leite JA AND Alvarenga CJ. 1992. Evolução tectono-sedimentar do Grupo Aguapeí, Proterozóico Médio na porção meridional do Cráton Amazônico: Mato Grosso e Oriente Boliviano. Rev Bras Geoc 23(1): 31-37.

Santos Jo, Hartmann LA, Gaudette He, Groves DI, MCNAUGhton NJ AND Fletcher IR. 2000. A new understanding of the provinces of the Amazon Craton based on integration of field mapping and $\mathrm{U}-\mathrm{Pb}$ and $\mathrm{Sm}-$ Nd geochronology. Gond Res 3: 453-488.

Santos JO, McNaughton NJ, Hartmann LA, Fletcher IR AND SALINAS RM. 2005. The age of the deposition of the Aguapeí Group, Western Amazon Craton, based on $\mathrm{U}-\mathrm{Pb}$ study on diagenetic xenotime and detrital zircon. In: Latin American Congress, Quito, Equador, Extended Abstracts, p. 1-4.

SAntos JO, Rizzotto GJ, EAston MR, Potter PE, Hartmann LA AND MCNAughton NJ. 2002. The Sunsás Orogen in Western Amazon Craton, South America and correlation with the Grenville Orogen of Laurentia, based on $\mathrm{U}-\mathrm{Pb}$ isotopic study of detrital and igneous zircons. In: Geological Society of America, 2002 Denver Annual Meeting (October 27-30, 2002), Precam Geol, p. 122-128.

Santos JO, Rizzotto GJ, Potter P, McNaughton N, Matos R, Hartmann LA, Chemale JR F AND Quadros ML. 2008. Age and autochthonous evolution of the Sunsás Orogen in West Amazon Craton based on mapping and $\mathrm{U}$ Pb geochronology. Precam Res 165: 120-152. 
SCANDOlara JE AND Rizzotto GJ. 1998. Programa Levantamentos Geológicos Básicos do Brasil. Paulo Saldanha Folha SC.20-Z-C-V. Estado de Rondônia. Escala 1:100.000. Brasilia: CPRM, 105 p.

SCANDOlara JE, RizzotTo GJ, AMORIM JL, BAHIA RB, QuAdros ML AND Silva CR. 1999. Geological map of Rondônia. 1:1.000.000. Companhia de Pesquisa de Recursos Minerais, Brasilia.

SouZA AA. 2011. Novos dados geocronológicos em zircões detríticos do Grupo Aguapeí (Formação Fortuna) na Serra da Borda, SW do Cráton Amazônico. In: $12^{\circ}$ Simpósio de Geologia da Amazônia, Boa Vista, CDROM.

SouZA AE AND HiLDRED PR. 1980. Contribuição ao estudo da geologia do Grupo Aguapeí, Mato Grosso. $31^{\circ}$ Congresso Brasileiro de Geologia 2: 587-598.

STACEY JS AND KRAMERS JD. 1975. Approximation of terrestrial lead isotope evolution by a two-stage model. Earth Plan Sci Lett 26: 207-221.

TAssinari CC, CORdani UG, NutMan AP, VAN SCHMUS WR, BETTENCOURT JS AND TAYLOR PN. 1996. Geochronological systematics on basement rocks from the Rio Negro-Juruena Province (Amazonian Craton) and tectonic implications. Int Geol Rev 38: 161-175.

TASSINARI CCG. 1993. Resultados radiométricos pelos métodos Rb-Sr e K/Ar de rochas do sudeste de Rondônia. CPRM, 9p. Relatório Interno.

Teixeira W, Geraldes mC, Matos R, Ruiz as, Saes G AND VARGAS-MATTOS G. 2010. A review of the tectonic evolution of the Sunsás belt, SW Amazonian Craton. Journ of South Am Earth Sci 29(1): 47-60.

Tohver E, Van Der Pluijm BA, Mezger K, Essene E, SCANDORALA JE AND RizzotTo GJ. 2004. Significance of the Nova Brasilândia metasedimentary belt in western Brazil: redefining the Mesoproterozoic boundary of the Amazon Craton. Tectonics. doi:10.1029/2003TC001563 (TC6004).
Tohver E, Van Der Pluijm BA, Mezger K, Scandolara JE AND ESSENE EJ. 2005b. Two stage tectonic history of the SW Amazon craton in the late Mesoproterozoic: identifying a cryptic suture zone. Precamb Res 137: 35-59.

Tohyer E, VAN Der Pluijm BA, Scandolara JE AND ESSENE E. 2005a. Late mesoproterozoic deformation of SW Amazonia (Rondonia, Brazil): geochronological and structural evidence for collision with Southern Laurentia. J Geol 113: 309-323. doi:10.1086/428807.

Tohver E, Teixeira W, Van Der Pluijm B, Geraldes M, BetTENCOURT JS AND Rizzotto GJ. 2006. Restored transect across the exhumed Grenville orogen of Laurentia and Amazonia, with implications for crustal architecture. Geology 34: 669-672.

WASTENEYS HA, ClARK AH, FARRAR E AND LANGRIDGE RJ. 1995. Grenvillian granulite-facies metamorphism in the Arequipa Massif, Peru: A Laurentia-Gondwana link: Earth Plan Sci Lett 132: 63-73.

WILLIAMS IS. 1998. U-Th-Pb geochronology by ion microprobe. In: MCKIBBEN MA, SHANKS III WC and RYDLEY WI (Eds), Applications of Microanalytical Techniques to Understanding Mineralizing Processes. Rev Econ Geol 7: 1-35.

WÖRNER G, LEZUAN J, BeCK A, HeBer V, LuCASSEN R, ZINNGREBE E, RÖSSLING R AND WILKE HG. 2000. Geochronology, petrology and geochemistry of basement rocks from Belen (N. Chile) and C. Uyarani (W. Bolivian Altiplano): Implications for the evolution of the Andean basement: Journ of South Am Earth Sci 13: 717-737.

YOUDEN WJ. 1951. Statistical methods for chemists. J. R. Stat. Soc. New York, Wiley, $126 \mathrm{p}$.

\section{SUPPLEMENTARY MATERIAL}

Appendix SA - Analytical Procedures 